\title{
Social sustainability assessment of shale gas in the UK
}

DOI:

10.1016/j.spc.2017.12.004

\section{Document Version}

Accepted author manuscript

Link to publication record in Manchester Research Explorer

\section{Citation for published version (APA):}

Cooper, J., Stamford, L., \& Azapagic, A. (2017). Social sustainability assessment of shale gas in the UK. Sustainable Production and Consumption. https://doi.org/10.1016/j.spc.2017.12.004

\section{Published in:}

Sustainable Production and Consumption

\section{Citing this paper}

Please note that where the full-text provided on Manchester Research Explorer is the Author Accepted Manuscript or Proof version this may differ from the final Published version. If citing, it is advised that you check and use the publisher's definitive version.

\section{General rights}

Copyright and moral rights for the publications made accessible in the Research Explorer are retained by the authors and/or other copyright owners and it is a condition of accessing publications that users recognise and abide by the legal requirements associated with these rights.

\section{Takedown policy}

If you believe that this document breaches copyright please refer to the University of Manchester's Takedown Procedures [http://man.ac.uk/04Y6Bo] or contact uml.scholarlycommunications@manchester.ac.uk providing relevant details, so we can investigate your claim.

\section{OPEN ACCESS}




\title{
Social sustainability assessment of shale gas in the UK
}

\author{
Jasmin Cooper, Laurence Stamford, Adisa Azapagic ${ }^{\star}$
}

School of Chemical Engineering and Analytical Science, The University of Manchester

The Mill, Room C16, Sackville Street, Manchester, M13 9PL, UK

${ }^{*}$ Corresponding author: adisa.azapagic@manchester.ac.uk

\begin{abstract}
The majority of shale gas studies so far have focused on environmental impacts with few considering societal aspects. This paper presents a first and most comprehensive assessment of the social impacts of shale gas production and utilisation for electricity generation, focusing on the UK context. The assessment has been carried out based on 14 indicators, addressing the following social sustainability issues: employment, health and safety, nuisance, public perceptions, local communities, infrastructure and resources. Shale gas is compared to a range of other electricity options, including other fossil fuels, nuclear and renewables. Where appropriate and possible, the social impacts are evaluated on a life cycle basis. The results suggest that extraction and utilisation of shale gas would lead to a range of benefits, including employment opportunities and financial gains by local communities. However, these are limited and countered by a number of social barriers that need to be overcome, including low public support, noise, traffic, strain on infrastructure (e.g. wastewater treatment facilities), land use conflict and availability of regulatory resources. Furthermore, shale gas does not present a notable opportunity for increasing energy security, unless its production increases significantly above current predictions. These findings can be used by policy makers, operators and other shale gas stakeholders with an interest in the social impacts of shale gas development. The results can also be useful for other countries planning to exploit their shale gas reserves.
\end{abstract}

Keywords: shale gas; fracking; hydraulic fracturing; electricity; social sustainability

\section{Introduction}

Shale gas is a controversial topic for various reasons, including the potential for water contamination, earthquakes and greenhouse gas emissions, which have fuelled opposition against its development (Cooper et al., 2016). Despite this, many nations are either producing it on a small scale or are in the early exploration stage because they wish to replicate the reduction in energy prices and improvement in energy security experienced in the US as a result of shale gas production. However, it is uncertain whether the US experience can be replicated, as environmental, economic and social impacts of shale gas in other countries are ambiguous or unknown. Social impacts are particularly underexplored, with most studies so far based in the US (e.g. Evensen et al., 2014; Hartley et al., 2015; Zirogiannis et al., 2016). As discussed below, these have considered issues such as employment, health and safety, nuisance, public perceptions, impact on local communities, infrastructure and resources.

Studies of employment have found that the development of shale gas can create a significant number of direct, indirect and induced jobs (Fullenbaum et al., 2011; Hartley et al., 2015). However, the financial gains to local communities are limited as workers are often outsiders, particularly in the US, staying in the area only temporarily. Furthermore, most direct jobs are in the pre-development stage and are thus short term.

Health and safety studies have focused on surveys of self-reported ailments experienced by residents living in shale gas-producing areas (Adgate et al., 2014; Rabinowitz et al., 2014; Steinzor et al., 2013). These include dizziness, headaches, eye and respiratory irritation (HSE, 2015; MDH, 2015; United States Department of Labor, 2015). It has also been suggested that those who live closer to well sites are more likely to experience ill-health (Rabinowitz et al., 2014). The causes of ill-health have been linked to wastewater pits (toxic chemicals becoming airborne during water evaporation), emissions from diesel equipment and exhaust fumes from trucks used to bring in 
equipment and materials. However, it should be noted that no professional medical diagnoses accompanied these illnesses self-reported in the surveys.

Studies on nuisance to humans and wildlife related to shale gas include traffic, noise and the presence of equipment. The increase in traffic volume has been linked to increased road accidents (Graham et al., 2015) and emissions of nitrogen oxides and particulate matter (Goodman et al., 2016). It has also been found that noise exposure near exploration sites can have adverse effects on human hearing (Hays et al., 2016) and can affect animal behaviour (Barber et al., 2010; Barber et al., 2011). There have been no studies on whether the noise has any impact on the health of birds but some studies found no adverse effect on population numbers (Barber et al., 2010; Barber et al., 2011). Similarly, the presence of equipment does not appear to have adverse effects on local wildlife or biodiversity (Jones et al., 2014). However, land transformation, in particular if it leads to forest fragmentation, can affect local biodiversity (Haddad et al., 2015).

A large number of studies have analysed public perceptions of shale gas and how they are influenced. Factors, such as demographics, risk perception, area of residence and political views, have been found to have a strong influence on people's attitudes towards shale gas (Israel et al., 2015; Theodori, 2012; Upham et al., 2015). Gender and education also appear to have an impact on perceptions (Boudet et al., 2013; Mukherjee and Rahman, 2016). A further influencing factor is how shale gas is represented in the media (Ashmoore et al., 2016; Jaspal and Nerlich, 2013; Jaspal et al., 2014). For example, when framed in the context of economic benefits and job generation, survey participants showed a positive attitude towards shale gas, but when framed in terms of climate change and environmental impacts, the attitudes tended to become negative (Christenson et al., 2017).

The impact on local communities has been evaluated in the literature considering community benefits, such as charters, benefit agreements and compensation schemes to offset damages caused by activities related to development. Most authors argue that there is a need for compensation and insurance schemes against environmental damage caused by shale gas development (Behrer and Mauter, 2017; ter Mors et al., 2012; Wetherell and Evensen, 2016). This is important as damage to the environment can affect the livelihoods of residents, such as ill-health and property value. However, US-based studies found that the latter is largely unaffected by shale gas development, with the exception of dwellings that rely of private wells for their water supply (Muehlenbachs et al., 2013). However, others have argued that the development of shale gas "urbanises" the countryside (Evans, 2016) which could affect property values in rural areas.

A further impact on local communities is migrant workers who tend to commute to work (sometime hundreds of miles, particularly in the US), resulting in an increase in housing rental prices and strain on local services (Jacquet, 2014; Muehlenbachs et al., 2015; Schafft et al., 2014). However, the influx boosts the local economy, although this dwindles as gas production matures and well productivity declines (Schafft et al., 2014; Tsvetkova and Partridge, 2016).

Another social aspect related to shale gas discussed in the literature is the impact on infrastructure and resources. The infrastructure required for the extraction of shale gas necessitates the use of equipment, materials, chemicals and labour (Adamus and Florkowski, 2016; Cooper et al., 2016). It also produces large amounts of wastewater (with high salinity, dissolved solids and radioactive elements) which needs to be treated, putting strain on existing water treatment facilities and potentially affecting local communities (Cooper et al., 2016). On the other hand, shale gas is a valuable resource and could contribute towards improved national energy security (Adamus and Florkowski, 2016; Cooper et al., 2016; IEA, 2011).

In addition to being US focused, the above-mentioned studies have only considered social impacts of the extraction and production of shale gas, omitting its utilisation. The latter is important for a better understanding of how to minimise adverse social impacts while maximising any gains that could be derived from the use of shale gas. It is also important to understand how the social impacts of shale gas compare to other energy sources, both during the production and use stages. Therefore, this paper evaluates social impacts of both shale gas production and utilisation for 
electricity generation and compares it to a range of other electricity options. As far as we are aware, this the first study of its kind internationally, also representing the most comprehensive assessment of the social sustainability of shale gas. The study focuses on the UK, one of the countries posed to commence commercial exploitation of shale gas. The main area of interest for exploitation is the Bowland-Hodder shale play in England, where around 4,000 shale gas wells are expected to be drilled over the next 15 years (Lewis et al., 2014). However, at the time of writing, only one well has been hydraulically fractured and another approved for hydraulic fracturing (Cuadrilla Resources, 2017; Gosden, 2016; Third Energy, 2016). Therefore, this study is timely and its findings can be used to inform developers, policy makers and the public on key social issues and how they could potentially be addressed. The results can also be useful for other countries planning to exploit their shale gas reserves.

\section{Methods}

In total, 14 indicators have been used to evaluate the social sustainability of shale gas; these are given in Table 1. They have been selected to cover the social issues identified in the literature discussed in the previous section, as well as to reflect UK-specific conditions (House of Lords, 2014). Hence, the indicators cover the following aspects:

- employment;

- health and safety;

- nuisance;

- public perceptions;

- local communities; and

- infrastructure and resources.

In addition to evaluating the social sustainability of shale gas, some of the indicators have been used to compare the social impacts of shale gas to other electricity options in the UK electricity mix. The electricity technologies considered are: conventional gas, liquefied natural gas (LNG), coal, nuclear, hydro, solar PV, wind (offshore) and biomass. Based on the relevance and data availability, the comparison is only possible for the following four indicators: direct employment, worker injuries, public support and diversity of fuel supply. The basis for comparison is determined by the units in which these indicators are measured; for the first two, the comparison is per TWh electricity generated and for the rest, it is dimensionless (see Table 1).

The methods and data used for the estimation of the indicators are detailed in the next sections.

Table 1: Indicators used to assess the social sustainability of shale gas

\begin{tabular}{|c|c|c|}
\hline Social issue & Indicator & Unit \\
\hline \multirow[t]{3}{*}{ Employment } & Direct employment $^{\mathrm{a}}$ & person-years/TWh \\
\hline & Local employment & $\%$ \\
\hline & Gender equality & - \\
\hline Health and safety & Worker injuries $^{a}$ & injuries/TWh \\
\hline \multirow[t]{2}{*}{ Nuisance } & Noise & $\mathrm{dB}$ \\
\hline & Traffic & $\%$ \\
\hline \multirow[t]{2}{*}{ Public perceptions } & Public support $^{\mathrm{a}}$ & $\%$ \\
\hline & Media impact & - \\
\hline \multirow[t]{2}{*}{ Local communities } & Spending on local or domestic suppliers & $\%$ \\
\hline & Direct community investment & $\%$ \\
\hline \multirow[t]{4}{*}{ Infrastructure and resources } & Diversity of fuel supply ${ }^{a}$ & - \\
\hline & Wastewater treatment & - \\
\hline & Land use & - \\
\hline & Regulatory resources & - \\
\hline
\end{tabular}

${ }^{a}$ Used for comparison with the other electricity options. 


\subsection{Employment}

\subsubsection{Direct employment}

This indicator measures the total number of jobs created directly due to shale gas production and utilisation. It is calculated on a life cycle basis, taking into account the number of jobs created along the supply chain, the duration of employment and the total amount of electricity generated over the lifetime of the power plant, based on the approach developed by Stamford and Azapagic (2012):

$\mathrm{DE}=\frac{\sum_{\mathrm{i}}^{\mathrm{l} D \mathrm{E}_{\mathrm{i}} \times \mathrm{t}_{\mathrm{i}}}}{\mathrm{P}_{\mathrm{tot}}}$

(person-years/TWh)

where:

$D E \quad$ total direct employment generated in the life cycle of shale gas electricity along the supply chain (person-years/kWh)

$D E_{i} \quad$ number of jobs created in life cycle stage $i$ (no. of persons)

$t_{i} \quad$ duration of employment in life cycle stage $i$ (years)

$P_{\text {tot }} \quad$ total amount of electricity generated over the lifetime of the power plant (TWh)

$i \quad$ life cycle stage

I total number of life cycle stages.

The DE has been calculated as part of this work for shale gas, LNG and hydropower and data for the estimation can be found in Table 2 and Table 3. For the remaining technologies, the DE values have been sourced from Stamford and Azapagic (2012). Indirect employment related to associated activities, such as production of chemicals or equipment, is beyond the scope of the study and is not considered.

Table 2: Power plant specification ${ }^{a}$ (Mishra and Singh, 2015; Statkraft, 2017; MacLeay et al., 2016; Mott MacDonald, 2010; Parsons Brinckerhoff, 2013)

\begin{tabular}{llll}
\hline Specification & Shale gas & LNG & Hydro \\
\hline Plant type & CCGT $^{\mathrm{b}}$ & CCGT $^{\mathrm{b}}$ & Reservoir \\
Lifetime (yr) & 25 & 25 & 30 \\
Electricity generation over lifetime (TWh) & 183 & 183 & 2.6 \\
\hline a Data used in eqns. (1) and (4). Specifications for the other technologies considered in this work are not shown as the \\
direct employment figures were not estimated here but taken from Stamford and Azapagic (2012). \\
bCCGT: combined cycle gas turbine.
\end{tabular}

Table 3: Data and assumptions for the estimation of direct employment (AMEC, 2013; Lewis et al., 2014; Statkraft, 2017; Cooper et al., 2014)

\begin{tabular}{llll}
\hline & \multicolumn{3}{l}{ Number of jobs $^{\mathrm{a}}$, persons } \\
Life cycle stage & Shale gas & LNG & Hydro \\
\hline Fuel extraction & $1203(1-30)^{\mathrm{b}}$ & - & - \\
Fuel transportation & $6(25)$ & $4054(0.1)^{\mathrm{c}}$ & - \\
Power plant construction & $800(3)$ & $800(3)$ & $400(3)$ \\
Power plant operation & $50(25)$ & $50(25)$ & $26(30)$ \\
Power plant decommissioning & $200(0.5)$ & $200(0.5)$ & $-\mathrm{e}$ \\
Liquefaction $^{d}$ & - & $160(30)$ & - \\
Regasification $^{\mathrm{d}}$ & - & $79(30)$ & - \\
Overhauls $^{\text {a }}$ & $200(0.2)$ & $200(0.2)$ & $30(0.5)$
\end{tabular}

${ }^{a}$ Total number of jobs needed to bring sufficient number of shale gas wells into operation to produce enough gas to sustain a power plant over its operating life. Number of jobs in LNG fuel extraction was assumed to be the same as UK offshore gas extraction and was sourced from Stamford and Azapagic (2012).

b Pad pre-development and preparation take up to a year and the producing lifespan of the well is 30 years.

c The shipment of LNG from Qatar to the UK takes two weeks and an LNG carrier has a crew of 30 (Maritime Connector, 2017 ; South Hook LNG Terminal, 2017). 135 LNG shipments are needed to provide a power plant with enough fuel to sustain it over its lifespan (Qatargas, 2017).

'LNG only.

${ }^{\text {e}}$ Decommissioning not considered as hydropower plants are typically refurbished instead of decommissioned (BHA, 2017). 
During the extraction of shale gas, 194 jobs are created per well, 40 in pre-development, 134 in pad preparations and 20 in gas production (AMEC, 2013; Lewis et al., 2014). To sustain a power plant over its lifespan, this work estimates that 6.2 shale gas well pad (248 wells) would be needed, based on data in Cooper et al. (2014) and Cooper (2017).

\subsubsection{Local employment}

Local employment measures contributions to the local economy and communities through the employment of local workforce during the extraction, production and utilisation of shale gas. The term "local" used here refers to the general area where the well site or power plant is situated and includes neighbouring communities within a commutable distance.

Local employment is defined as the percentage of new jobs created that could be filled by workers from local communities and is calculated as follows (Stamford and Azapagic, 2012):

$P_{L E}=\frac{L E}{T E} \times 100$

where:

$P_{L E} \quad$ proportion of employees that could be hired from the local community (\%)

$L E$ number of employees that could be hired from the local community (persons-years/TWh)

TE total number of employees needed (persons-years/TWh).

For the data used to calculate local employment, see Table 4.

Table 4: Data and assumptions for the estimation of local employment in the life cycle of shale gas

\begin{tabular}{lccl}
\hline Life cycle stage & $\begin{array}{c}\text { Number of } \\
\text { local } \\
\text { employees }\end{array}$ & $\begin{array}{c}\text { Total number } \\
\text { of employees } \\
\text { needed }\end{array}$ & Source \\
\hline Well pad pre-development & 241 & 241 & Lewis et al. (2014); Rigzone (2014) \\
Pad preparation & 582 & 831 & Lewis et al. (2014); Rigzone (2014) \\
Gas production and processing & 73 & 124 & Lewis et al. (2014); Rigzone (2014) \\
Gas distribution & 6 & 6 & Lewis et al. (2014); Rigzone (2014) \\
Power plant operation & 50 & 50 & Cooper (2015); EDF Energy (2017) \\
Power plant construction & 800 & 800 & Cooper (2015); Hendry (2011) \\
Power plant decommissioning & 200 & 200 & Hendry (2011) \\
\hline
\end{tabular}

\subsubsection{Gender equality}

Diversifying the workforce is important as the workforce in the gas sector is predominantly male (Oil and Gas UK, 2015). Therefore, the gender equality indicator aims to capture the workforce diversity by measuring the ratio of male to female workers. A scale ranging from -1 to 1 has been used in this work, with -1 representing no female workers and 1 an entirely female workforce; 0 represents an equal split of the genders, assumed as an ideal situation. This indicator is estimated according to the following equation and data in Table 5 (which also shows data for some other countries for comparison):

$\mathrm{GE}=\frac{\mathrm{FW}}{50}-1$

where:

GE gender equality index (-)

FW percentage of female workforce (\%). 
Table 5: Percentage of male and female workforce in the oil and gas industry in the UK and some other countries (Czebiniak, 2014; McGrath and Marinelli, 2012; Oil \& Gas UK, 2011)

\begin{tabular}{lcc}
\hline Country & Female workforce (\%) & Male workforce (\%) \\
\hline UK & 3.7 & 96.3 \\
Norway & 19 & 81 \\
Australia & 12 & 88 \\
Canada & 21 & 79 \\
US & 15 & 85 \\
\hline
\end{tabular}

\subsection{Health and safety: worker injuries}

This indicator measures workers' safety across the supply chain related to shale gas production and utilisation. Like direct employment, it is also estimated on a life cycle basis considering the total electricity generated over the lifetime of the power plant, injury rates and employment across the supply chain:

$\mathrm{WI}=\sum_{\mathrm{i}}^{l} \mathrm{E}_{\mathrm{i}} \mathrm{r}_{\mathrm{i}} \quad$ (injuries/TWh)

where:

WI number of worker injuries (injuries/TWh)

$E_{i} \quad$ employment in life cycle stage $i$ (person-years/TWh)

$r_{i} \quad$ annual injury rate in life cycle stage $i$ (injuries/person-years).

The data used to estimate worker injuries related to shale gas, LNG and hydro are summarised in Table 5; they refer to the year 2014/2015. Injuries included in the estimate are fatalities, major injuries and less serious injuries that cause an absence from work of more than three days. The injury rates for the other technologies have been sourced from Stamford and Azapagic (2012) based on the same definition of injuries as above.

Table 6: Data and assumptions for the estimation of worker injuries by life cycle stage (HSE, 2014; HSE, 2017; Ministry of Public Health (State of Qatar), 2017).

\begin{tabular}{lccc}
\hline & \multicolumn{3}{c}{ Injury rate (injuries/1000 workers) } \\
\hline Life cycle stage & Shale gas & \multicolumn{1}{c}{$L N G^{a}$} & Hydro \\
\hline Well pad pre-development & 4.50 & 15.66 & - \\
Pad preparation & 4.50 & 15.66 & - \\
Gas production and processing & 4.50 & 15.66 & - \\
Gas distribution $^{\text {Liquefaction }}{ }^{\mathrm{b}}$ & 1.86 & 4.57 & - \\
Regasification $^{\mathrm{D}}$ & - & 4.57 & - \\
Power plant operation & - & 4.57 & - \\
Power plant construction & 1.86 & 1.86 & 1.86 \\
Power plant decommissioning & 29.42 & 29.42 & 29.42 \\
\hline
\end{tabular}

${ }^{a}$ LNG considered only the liquefaction, transport and gasification.

${ }^{b}$ LNG only.

\subsection{Nuisance}

\subsubsection{Noise}

The potential impact of noise on local residents has been evaluated using literature data for noise expected during shale gas production (Arup, 2014a). These data are compared to the recorded noise levels from the US and, for context, to the noise levels of other activities, such as traffic, music and conversation (Arup, 2014a; MDE and DNR, 2015; NIDCD, 2010; Vondra, 2014).

\subsubsection{Traffic}

An increase in road traffic heading towards well sites is expected due to the need to bring equipment, people and materials to and from the site. The expected increase in traffic volume on roads around well sites in the UK has been estimated based on the congestion reference flow (CRF). The CRF considers traffic characteristics and road types and is used as a measure of a 
likely increase in traffic congestion during peak (rush) hours. The CRF is calculated as follows (Standards for Highways, 1997; Standards for Highways, 1999):

$C R F=C A P \times L \times W_{f} \times \frac{100}{P k F} \times \frac{100}{P k D} \times \frac{A A D T}{A A W T} \quad$ (vehicles/day)

where:

$C R F$ congestion reference flow (vehicles/day)

CAP maximum vehicle capacity per road lane (vehicles/day)

$L \quad$ number of lanes on the road (-)

$W_{f} \quad$ width factor - width of road lanes relative to a standard width of $3.65 \mathrm{~m} \mathrm{(-)}$

$P k F \quad$ proportion of daily traffic flow during peak hours (-)

$P k D$ the directional split of traffic flow during peak hours (-)

$A A D T$ the annual average daily traffic flow (vehicles/day)

$A A W T$ the annual average weekday flow (vehicles/day).

The CRF has been estimated for both urban and rural roads using literature data (Broderick et al., 2011); for details, see Tables S1 and S2 in the Supporting Information (SI). The data suggest that between 2-659 truck trips would be needed during the different shale gas pre-development activities. On average, this translates to $0.36-14$ truck trips per day to bring a well into operation. These are for delivering and removing equipment and materials to and from the site as well as for removing waste. The large range in the number of possible trips is due to the different types of activity carried out. For example, constructing and drilling the well pad as well as hydraulic fracturing will require a lot of (non-permanent) equipment and materials and will, consequentially, cause significant truck traffic. On the other hand, waste disposal and well cleaning and testing will need less equipment and resources and will require a lower number of trips.

The CRF has only been calculated for well site development and does not include the traffic that would be incurred by wastewater removal from the site. This is because the volume of wastewater produced is highly variable and uncertain (see Section S7.2 in the SI) and transportation of wastewater can be affected by water management strategies, such as onsite storage, treatment and recycling. Furthermore, wastewater shipments can be carried out outside the peak hours, therefore not affecting the CRF. Wastewater transportation is discussed further in sections 2.6.2 and 3.6.2.

\subsection{Public perceptions}

\subsubsection{Public support}

Previous studies have used surveys to assess what percentage of participants are 'pro', 'unsure/neutral' or 'anti' shale gas. While this information is useful, it does not allow for an overall evaluation of public support - or the lack of - for shale gas. Therefore, a single measure, termed 'public support index' (PSI), has been developed as part of this work. Using averaged data from various public-perception surveys (Castell et al., 2014; DECC, 2014; O'Hara et al., 2015), the PSI is calculated as the difference between the percentage support and opposition for each electricity option. The 'unsure/neutral' responses are not considered; however, they can affect the overall PSI score by reducing the number of those in support or opposition, as discussed in the Section 3.4.1. The PSI can range from $-100 \%$ to $100 \%$, where the former represents complete opposition and the latter complete support.

The data used for the calculation of the public support index have been collected from numerous surveys and their results averaged to calculate the values listed in Table 7 . This approach has been taken because the level of support/opposition for shale gas and other electricity options differed significantly across the surveys. This variation is illustrated for shale gas in Figure 1. Differences in the results can be attributed to various factors, such as the framing of questions, sample sizes, timing of survey and geographical location of people surveyed. 
Table 7: Data for the calculation of the public support index (ComRes, 2015; Cunningham, 2014; DECC, 2015; Spence et al., 2010; Wire and staff reports, 2008)

\begin{tabular}{ccccccrrrr}
\hline $\begin{array}{c}\text { Public } \\
\text { opinion }\end{array}$ & $\begin{array}{c}\text { Shale } \\
\text { gas }\end{array}$ & $\begin{array}{c}\text { Conventional } \\
\text { gas }\end{array}$ & LNG & Coal & Hydro & Nuclear & $\begin{array}{c}\text { Solar } \\
\text { PV }\end{array}$ & $\begin{array}{c}\text { Offshore } \\
\text { wind }\end{array}$ & Biomass \\
\hline Support (\%) & 37 & 56 & 42 & 36 & 76 & 33 & 81 & 73 & 63 \\
Oppose (\%) & 32 & 22 & 27 & 43 & 4 & 24 & 6 & 8 & 6 \\
Unsure (\%) & 31 & 22 & 31 & 22 & 20 & 43 & 14 & 19 & 30 \\
\hline
\end{tabular}

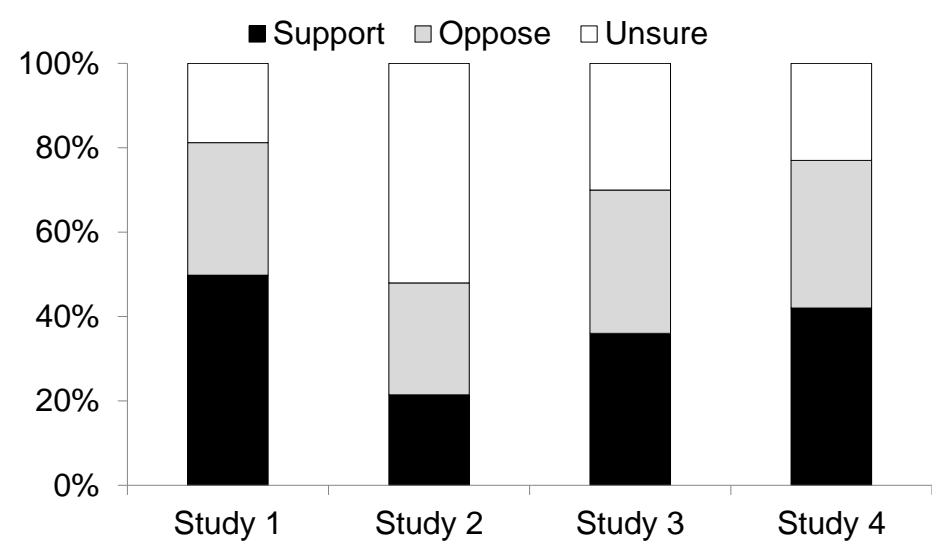

Figure 1: Comparison of public attitudes towards shale gas in the UK in different studies [Study 1: O'Hara et al. (2015); Study 2: DECC (2015); Study 3: Castell et al. (2014); Study 4: ComRes (2015)].

\subsubsection{Media impact}

As mentioned in the introduction, people's opinions on shale gas are influenced by the way shale gas is represented in the media (Ashmoore et al., 2016; Jaspal and Nerlich, 2013; Jaspal et al., 2014). In an attempt to capture this, the representation of shale gas in the media by its proponents, opponents and neutral stakeholders is considered through a 'media impact index' (MII) developed as part of this work. The MII uses the presence of different stakeholders in the media as a proxy, assuming that greater presence has a greater potential to influence people's opinions. The focus is on the social media and specifically on the five most popular platforms: Twitter, Facebook, Linkedln, Google+ and YouTube (Small Business Trends, 2015; Social Media Today, 2015). Three stakeholder groups are considered, representing potential key opinion formers: main shale gas operators, government and academic bodies and non-governmental organisations (NGOs). They span the full spectrum of attitudes towards shale gas, respectively from 'pro' through 'unsure/neutral' to 'anti'. The operators considered are Cuadrilla Resources, iGas and Third Energy and the main material they post on the social media, in addition to technical information on shale gas, is related to their support for local communities and events. The most prominent anti-shale NGOs included here are Greenpeace and Friends of the Earth who post various information in opposition to the UK developing shale gas. The government and academic bodies considered (Department of Energy and Climate Change, Environment Agency and the University of Manchester) are overall neutral in their postings, mainly providing links to information on shale gas extraction and development in the UK. Their presence across the five social media platforms is detailed in Table S2 in the SI.

The MII is estimated as follows:

$\mathrm{MII}_{\mathrm{S}}=\frac{\mathrm{P}_{\mathrm{S}}}{\mathrm{P}_{\mathrm{T}}}$

where:

$M I I_{s} \quad$ total media impact of stakeholder $s(-)$

$P_{s} \quad$ total presence of stakeholder $s$ on all social media platforms considered (-)

$P_{T} \quad$ total presence of all stakeholders on all social media considered (-). 
The impact, $M I_{s}$, is measured on a scale from 0 to 1 , with 1 representing complete dominance and 0 no or minimal presence and impact.

The presence $P_{s}$ of stakeholder $s$ on each social media platform $\left(P_{s, j}\right)$ is estimated taking into account their presence as measured by different types of metrics $j$, such as number of tweets, 'likes' and followers (see Table S2) according to:

$P_{s, j}=\frac{n_{s, j}}{n_{j}(\max )}$

where:

$P_{s, j} \quad$ presence of stakeholder $s$ for metrics $j(-)$

$n_{s, j} \quad$ value of metrics $j$ (e.g. number of tweets, 'likes', etc.) for stakeholder $s(-)$

$n_{j(\max )}$ the highest value of metrics $j(-)$

$j \quad$ type of metrics (e.g. tweets, 'likes', etc.).

The presence $P_{s}$ of each stakeholder across all social media platforms is then estimated as:

$\mathrm{P}_{\mathrm{s}}=\sum_{\mathrm{j}}^{\mathrm{J}} \mathrm{P}_{\mathrm{s}, \mathrm{j}}$

where:

$J \quad$ total number of social media metrics (-).

The total presence of all stakeholders on all the social media platforms $P_{T}$ is equal to:

$\mathrm{P}_{\mathrm{T}}=\sum_{\mathrm{m}}^{\mathrm{M}} \mathrm{P}_{\mathrm{s}}$

where:

$m \quad$ social media platform (-)

$M \quad$ total number of social media platforms (-).

\subsection{Local communities}

\subsubsection{Spending on local or domestic suppliers}

The spending on supplies needed for shale gas presents an opportunity for both the local and the national economy. Thus, this indicator measures the proportion of total potential spending by shale gas operators on equipment, materials or services that could be sourced from local or domestic suppliers over 15 years, the time it takes for the shale gas industry to mature (Lewis et al., 2014). It is calculated as follows (Stamford and Azapagic, 2012):

$P_{L S}=\frac{S_{L S}}{S_{T}} \times 100$

where:

$P_{L S} \quad$ percentage of total potential spending on local or domestic suppliers (\%)

$S_{L S} \quad$ total potential spending on local or domestic suppliers $(£)$

$S_{T} \quad$ total potential expenditure on suppliers (£).

The data for estimating $P_{L S}$ for the development of 4000 shale gas wells can be found in Table 8 . The potential spending on local or domestic suppliers $S_{L S}$ shown in the table has been determined based on whether there is already an industry in the UK for the equipment and services needed (Lewis et al., 2014). 
Table 8: Potential costs of bringing $\mathbf{4 0 0 0}$ shale gas wells into operation in the UK

\begin{tabular}{lrr}
\hline Category & $\begin{array}{c}\text { Total potential } \\
\text { spending } \\
\text { (million } \mathbf{~})^{\mathbf{a}}\end{array}$ & $\begin{array}{c}\text { Potential spending on local or } \\
\text { domestic suppliers } \\
(\%)\end{array}$ \\
\hline Specialised hydraulic fracturing equipment & 17,000 & 0 \\
Sand & 2000 & 100 \\
Chemicals & 748 & 100 \\
Steel casing & 2300 & 100 \\
Drilling rigs & 2200 & $0-100$ \\
Ancillary and services & 1200 & 100 \\
Cement & 819 & 100 \\
Directional drilling & 747 & $0-100$ \\
Drilling fluid & 571 & 100 \\
Drill rig fuel & 457 & 100 \\
Wastewater treatment and management & 1500 & 100 \\
Drilling waste management & 1300 & 100 \\
Water transport and storage & 523 & 100 \\
Waste transport and storage & 754 & 100 \\
Total & 32,119 & \\
\hline
\end{tabular}

${ }^{a}$ Over 15 years, time required for UK shale gas industry to reach maturity (Lewis et al., 2014).

\subsubsection{Direct community investment}

This indicator measures investments in and donations to local communities by operators across the shale gas electricity supply chain through various schemes to offset damage caused by activities related to shale gas development. In the UK, these include the community charter and the shale gas wealth fund (Cronin, 2013; HM Treasury, 2016; Oil and Gas UK, 2015; UKOOG, 2013). It is estimated as a percentage of the operator's total annual revenue (Stamford and Azapagic, 2012):

$\mathrm{P}_{\mathrm{LI}}=\frac{\mathrm{LI}}{\mathrm{R}_{\mathrm{T}}} \times 100$

where:

$P_{L I} \quad$ percentage of direct investment into the local community (\%)

$\mathrm{LI} \quad$ annual investment in and donations to the local community ( $£ /$ year)

$R_{T} \quad$ total annual revenue (£/year).

The data used for the estimation of this indicator can be found in Table 9.

Table 9: Data for the estimation of direct community investment (National Grid, 2017; Cooper, 2017; npower, 2017)

\begin{tabular}{|c|c|c|c|}
\hline Operator & $\begin{array}{l}\text { Annual community investment } \\
\text { (million } £ / y r)\end{array}$ & $\begin{array}{l}\text { Annual revenue } \\
{\text { (million } £ / y r)^{a}}^{a}\end{array}$ & $\begin{array}{l}\text { Operating lifespan } \\
\text { (years) }^{\mathrm{b}}\end{array}$ \\
\hline Shale gas & $0.47-0.89$ & $47-89$ & 30 \\
\hline Gas distribution & 0 & 15,115 & - \\
\hline Power plant & $4.10-10$ & $399-582$ & 25 \\
\hline
\end{tabular}

\subsection{Infrastructure and resources}

2.6.1. Diversity of fuel supply

The diversity of fuel supply (DFS) is a measure of national energy security - the more diverse the fuel supply, the greater the energy security, reducing dependency on any one fuel or supplier. This 
is measured on a scale of $0-1$, where 0 represents complete dependence on a single country for all fuel/energy needs (indicating a high risk of energy disruption) and 1 represents complete selfsufficiency (a low risk of energy disruption). The DFS is calculated as follows (Stamford and Azapagic, 2012):

$$
\mathrm{DFS}=\mathrm{P}_{\mathrm{in}}+\mathrm{P}_{\mathrm{im}}\left(1-\frac{\sum_{\mathrm{c}}^{\mathrm{C}} \mathrm{P}_{\mathrm{im}, \mathrm{c}}\left(\mathrm{P}_{\mathrm{im}, \mathrm{c}-1)}\right)}{9900}\right)
$$

where:

DFS diversity of fuel supply mix (-)

$P_{\text {in }} \quad$ proportion of fuel consumption from domestic resources (-)

$P_{i m} \quad$ proportion of fuel consumption from imported resources (-)

$P_{i m, c} \quad$ proportion of fuel imports supplied by exporting country $\mathrm{C}$

$c$ exporting country

C total number of exporting countries.

The DFS has been estimated for shale gas as well as the other fuels used for generating electricity in the UK. The impact of shale gas on the UK energy mix has also been assessed by calculating the DFS for the present (2012) and future (2030) UK gas and electricity mixes. The latter consider two scenarios: low and high shale gas penetration, respectively. The data for these estimations are given in Table 10 and Table 11. The DFS of the gas and electricity mix scenarios has been calculated by multiplying the DFS of each electricity option by their percentage contribution to the mix (obtained from Table 10 and Table 11) and then adding these together. The current supply mix of the fuels for other electricity options is given in Table S4 in the SI. The supply mix in 2030 is assumed to be the same as at present due to a lack of data on future fuel supplies.

Table 10: UK gas mix at present (DECC, 2013a) and in 2030 (adapted from Williams et al. (2011))

\begin{tabular}{|c|c|c|c|}
\hline Gas source & $\begin{array}{l}2012 \\
\left(\text { bn m }^{3}\right)\end{array}$ & $\begin{array}{l}2030 \text { (low shale } \\
\text { gas penetration) } \\
\left(\text { bn } \mathrm{m}^{3}\right)\end{array}$ & $\begin{array}{l}2030 \text { (high shale } \\
\text { gas penetration) } \\
\left(\text { bn } \mathrm{m}^{3} \text { ) }\right.\end{array}$ \\
\hline UK north sea & 42 & 16 & 16 \\
\hline UK shale gas & 0 & 4 & 25 \\
\hline Pipeline imports-Norway & 27 & 33 & 33 \\
\hline Pipeline imports-Netherlands & 7 & 10 & 10 \\
\hline Pipeline imports-Belgium & 1 & 0 & 0 \\
\hline LNG imports-Qatar & 14 & 25 & 4 \\
\hline Total & 91 & 88 & 88 \\
\hline
\end{tabular}

Table 11: UK electricity mix at present and in 2030 (DECC, 2013a; DECC, 2013b)

\begin{tabular}{lcc}
\hline Electricity source & $\mathbf{2 0 1 2}$ (TWh) & $\mathbf{2 0 3 0}$ (TWh) \\
\hline Coal & 135.9 & $18.5^{\mathrm{a}}$ \\
Oil & 2.7 & 3.6 \\
Natural gas & 98.2 & $101.2^{\mathrm{a}}$ \\
Nuclear & 63.9 & 101.9 \\
Wave, wind and solar & 20.8 & 113.0 \\
Other & 32.4 & 46.9 \\
Total & $\mathbf{3 5 3 . 9}$ & $\mathbf{3 8 5 . 1}$ \\
\hline
\end{tabular}

\footnotetext{
${ }^{a}$ Includes 16.7 TWh of coal and gas CCS each, respectively. The split between coal and gas CCS was not Retrieved from so an equal split was assumed.

${ }^{b}$ Hydroelectricity, biomass, fuel oil and electricity imports.
}

\subsubsection{Wastewater treatment}

In the UK, wastewater produced from hydraulic fracturing must be treated in a wastewater treatment plant before it can be discharged into open water bodies (DECC, 2014). As treatment works are constantly in operation, it is important that the volume of wastewater produced does not cause strain to existing facilities and overload them. Otherwise, this could cause problems to 
communities served by these treatment plants, including their temporary shutdown, discharge of inadequately treated water into the environment and related nuisance and human health impacts. To assess the potential for this, the volume of wastewater produced by a shale gas well has been compared to the treatment capacity of facilities in and close to the Bowland-Hodder shale play, the main area of shale gas interest and development in the UK. A further aspect considered is the need to transport wastewater by tankers from well sites to these facilities as this would affect communities living nearby; hence the number of tanker trips required has also been calculated. The data for the estimations associated with wastewater treatment are provided in Table 12 and Table 13.

As indicated in Table 12, hydraulic fracturing requires large volumes of water, of which $10 \%-300 \%$ returns to the surface as flowback fluid (wastewater), resulting in large quantities of wastewater. However, the total volume produced is spread out throughout the well's lifespan. In the first two to four weeks after well completion, around $10 \%-40 \%$ of the injected fluid $\left(871\right.$ to $10,000 \mathrm{~m}^{3}$ ) returns to the surface (Clark et al., 2013; Lutz et al., 2013). Any remaining fluid which returns to the surface will do so later on. This will also affect the requirements for transport of wastewater, discussed in Section 2.3.2. Thus, the number of truck trips required to transport wastewater to the treatment facility is expected to be the highest in the first month, as the rate at which water returns to the surface after the initial period is much lower. Planning transport based on predicted volumes during set periods of the well's life can help in managing transporting and on-site storage for wastewater as well as the load on the water treatment plant.

The wastewater treatment plants given in Table 13 are those within and close to the UK's Bowland-Hodder shale play catchment area which are capable of treating trade effluent and could be suitable for treating wastewater from shale gas wells. Their treatment capacity and maximum flow (to full treatment) have been used to calculate how long it would take each facility to treat the total amount of wastewater produced by a well over its lifespan. While other plants are also Retrieved from in the catchment area (Andrews, 2013; Google Earth, 2015; UK water projects online, 2015), the majority are small facilities, only capable of treating domestic wastewater. These would be unsuitable for hydraulic fracturing wastewater as it has a high concentration of dissolved solids and contains other chemicals not found in domestic wastewater (Cooper et al., 2016).

Table 12: Flowback fluid volume ranges ${ }^{a}$ (Clark et al., 2013; Freyman and Salmon, 2013)

\begin{tabular}{lcc}
\hline Flowback (\%) & $\begin{array}{l}\text { Low hydraulic fracturing } \\
\text { volume }\left(\mathbf{8 7 0 6} \mathbf{~ m}^{\mathbf{3}}\right)\end{array}$ & $\begin{array}{l}\text { High hydraulic fracturing } \\
\text { volume }\left(\mathbf{2 5 , 0 0 0} \mathbf{~ m}^{\mathbf{3}}\right)\end{array}$ \\
\hline 10 & 871 & 2500 \\
20 & 1741 & 5000 \\
30 & 2612 & 7500 \\
40 & 3482 & 10,000 \\
50 & 4353 & 12,500 \\
60 & 5224 & 15,000 \\
70 & 6094 & 17,500 \\
75 & 6530 & 18,750 \\
100 & 8706 & 25,000 \\
150 & 13,059 & 37,500 \\
200 & 17,412 & 50,000 \\
300 & 26,118 & 75,000 \\
\hline
\end{tabular}

${ }^{\mathrm{a}}$ For context, an Olympic-size swimming pool has the volume of $2500 \mathrm{~m}^{3}$. 
Table 13: Wastewater treatment works data (UK water projects online, 2015)

\begin{tabular}{lccc}
\hline $\begin{array}{l}\text { Wastewater treatment } \\
\text { plant }\end{array}$ & $\begin{array}{c}\text { Treatment capacity } \\
\left(\mathbf{m}^{\mathbf{3}} \mathbf{\text { day }}\right)\end{array}$ & $\begin{array}{c}\text { Flow to full treatment } \\
\left(\mathbf{m}^{\mathbf{3}} \mathbf{s}\right)\end{array}$ & $\begin{array}{c}\text { Time to treat } \\
\text { wastewater }(\mathbf{h o u r s})\end{array}$ \\
\hline Bromborough & 33,367 & 0.71 & $0.34-29.55$ \\
Davyhulme & 385,000 & 9.09 & $0.03-2.29$ \\
Liverpool & 256,667 & 11.00 & $0.02-1.89$ \\
Wigan & 89,833 & 1.93 & $0.13-10.78$ \\
Blackburn Meadows & 205,333 & 1.83 & $0.13-11.39$ \\
Denaby, Mexborough & 8983 & 0.21 & $1.13-97.35$ \\
and Burcroft combined & & & \\
Huddersfield & 37,987 & 1.37 & $0.18-15.18$ \\
Knostrop & 256,667 & 5.28 & $0.05-3.95$ \\
Clay Mills & 108,282 & 1.30 & $0.19-15.98$ \\
Derby & 128,333 & 2.38 & $0.10-8.74$ \\
Stoke Bardolph & 166,833 & 1.97 & $0.12-10.59$ \\
Strongford & 89,833 & 2.74 & $0.09-7.61$ \\
Wanlip & 231,000 & 3.59 & $0.07-5.81$ \\
Chester & 32,360 & 0.92 & $0.26-22.60$ \\
Five Fords & 24,640 & 0.81 & $0.30-25.85$ \\
\hline
\end{tabular}

\subsubsection{Land use}

Conflict over the use of land at sites of special cultural, scientific, recreational and other interest could have significant implications for shale gas development as such sites are protected, limiting the area Retrieved from for drilling. On the other hand, making these sites Retrieved from for shale gas exploitation, would meet with significant opposition by the public and organisations that own or manage those sites. To assess potential conflicts related to land use, the Bowland-Hodder shale play and sites of special interest have been mapped out using Google Earth (2015). A map of major cities in relation to the shale play has also been plotted to identify any further land-conflict issues; these figures are presented and discussed in Section 3.6.3. The sites of cultural and scientific importance selected are:

- national parks;

- special areas of conservation (SAC);

- $\quad$ special protected areas (SPA);

- $\quad$ areas of outstanding natural beauty (AONB);

- UNESCO World Heritage sites;

- Natura2000 and Ramsar sites;

- English Heritage sites; and

- local nature reserves.

\subsubsection{Regulatory resources}

The deep horizontal drilling and high pressure hydraulic fracturing needed for extracting shale gas are not being carried out in the UK at present. Therefore, new regulatory schemes are required to ensure compliance with standards and to avoid problems associated with well integrity, leaks, emissions and waste treatment. It has been estimated that the UK could have up to 4000 commercial and operational shale gas wells, with 400 wells being drilled during peak activity (Lewis et al., 2014). Consequently, the availability of skilled staff, particularly inspectors, in regulatory bodies is critical for proper regulation enforcement (DECC, 2013c). In the UK, shale gas operators must obtain a licence for exploration and development from the Department of Business, Energy and Industrial Strategy (BEIS), environmental permits from relevant environment agency and numerous other permits and permissions from other regulatory bodies (DECC, 2013c). Once all permits and permissions are obtained, BEIS gives the final consent on whether exploration/development can proceed (DECC, 2013c; EA, 2012). As BEIS is the main regulatory body involved, the number of regulatory staff they have Retrieved from has been considered here. However, other regulatory bodies such as the Environment Agency (EA) and Health and Safety Executive (HSE) would also be involved in monitoring permit and licence compliance (DECC, 2013c; EA, 2012). 
The number of inspectors needed to ensure wells are in compliance with their permits has been estimated based on US standards, where one full time inspector should be in charge of no more than 300 wells and wells require seven inspections prior to production, a minimum of one check-up per year during production and three examinations after decommissioning (Earthworks, 2012a; Earthworks, 2012b; Western Organization of Resource Councils, 2013). If there are reports of violations or inspection failures, additional inspections will be required. Based on this, the total (minimum) number of inspections required has been calculated to determine the minimum number of inspectors required. This estimate is compared to the number of inspectors currently employed for the regulation of the UK oil and gas industry (DECC, 2013c; DECC, 2011) to assess whether current staff numbers are adequate and if and how many additional inspectors may be needed.

\section{Results and discussion}

\subsection{Employment}

\subsubsection{Direct employment}

The development of shale gas in the UK is expected to generate between 32,000 and 74,000 direct, indirect and induced jobs (AMEC, 2013; Cooper et al., 2016; Taylor and Lewis, 2013). Based on the US experience (Fullenbaum et al., 2011), the majority of these are likely to be induced jobs while the number of direct jobs is expected to be relatively small, particularly in comparison with other fuel supply chains.

The direct employment (DE) values in different life cycle stages of shale gas electricity, estimated using the data in Table 2 and Table 3 and eqn. (1) are given in Table 14. As evident, fuel extraction is the biggest source of employment, with 26.2 person-years/TWh out of the total of 47.6 personyears/TWh. This is due to the numerous stages involved in the preparation of a well pad (e.g. its construction, transport and installation of equipment, etc.) and the number of wells needed to produce enough gas to sustain the power plant over its life time. The next largest contributors to DE are power plant construction and operation (13.1 and 6.8 person-years/TWh, respectively), owing to the significant workforce needed to build the power plant and its continuous operation over the lifetime. On the other hand, the number of staff needed for fuel transportation, power plant decommissioning and overhauls is low (0.2-0.8 person-years/TWh) as these activities require only a handful of engineers and site operators or are short term (up to six months).

The direct employment estimated to be created in the life cycle of shale gas electricity is compared to the other sources of electricity in Table 15. As can be seen, shale gas has the lowest employment, followed by conventional gas at 62 person-years/TWh. By contrast, the highest employment of 782 person-years/TWh is provided in the life cycle of hydroelectricity. In general, the fossil fuels (bar LNG) and nuclear have a smaller DE than the renewable options. LNG has a relatively high DE because of the jobs created in the liquefaction, regasification and shipping stages. The renewables have a significantly higher DE because of the workforce needed for maintenance (wind and solar), construction (hydro) and feedstock cultivation and processing (biomass). Renewable options also tend to have a lower generation capacity than the fossil fuels and nuclear, which is why they have higher employment levels per unit electricity generated.

Table 14: Number of jobs created in the life cycle of shale gas

\begin{tabular}{lc}
\hline Life cycle stage & Direct employment, $\boldsymbol{D E}$ (person-years/TWh) $^{\text {a }}$ \\
\hline Fuel extraction & 26.2 \\
Fuel transportation & 0.8 \\
Power plant construction & 13.1 \\
Power plant operation & 6.8 \\
Power plant decommissioning & 0.5 \\
Overhauls & 0.2 \\
Total & $\mathbf{4 7 . 6}$ \\
\hline a &
\end{tabular}

${ }^{a}$ Total number of jobs needed to bring sufficient number of shale gas wells into operation to produce enough gas to sustain a power plant over its operating life. 
Table 15: Direct employment in the life cycle of shale gas and other electricity options ${ }^{a}$.

\begin{tabular}{lc}
\hline Electricity option & $\begin{array}{c}\text { Direct life cycle employment, DE } \\
\text { (person-years/TWh) }\end{array}$ \\
\hline Shale gas & 47.6 \\
Conventional gas & 62.0 \\
LNG & 326.9 \\
Coal & 191.0 \\
Nuclear & 87.0 \\
Hydro & 782.4 \\
Solar PV & 653.0 \\
Offshore wind & 368.0 \\
Biomass & 385.8 \\
\hline a The results for shale gas, LNG and hydro are estimated in this work. The results for the other electricity options are \\
sourced from Stamford and Azapagic (2012).
\end{tabular}

\subsubsection{Local employment}

Out of the above-mentioned $32,000-74,000$ jobs expected to be created by shale gas exploitation, $27,500-64,000$, or $86 \%$, are estimated in this work to be Retrieved from to locals across the life cycle of shale gas electricity. Based on the data in Table 4 and eqn. (2), percentage local employment $P_{L E}$ in the different life cycle stages ranges from $59 \%$ for drilling and hydraulic fracturing jobs to $70 \%$ for exploration and site preparation to $100 \%$ for the rest of the supply chain (Table 16). The reason for a lower local employment in some stages is because they require specialist labour which is not Retrieved from locally, such as hydraulic fracturing engineers and specialised geo-scientists (Lewis et al., 2014). These specialist roles often require previous experience (Rigzone, 2014), leading to the expectation that labour for specialist jobs will more than likely need to be imported from abroad (e.g. from the US) where experienced workers can be found.

Table 16: Local employment potential in the life cycle of shale gas electricity

\begin{tabular}{lc}
\hline Life cycle stage & Percentage local employment, $\boldsymbol{P}_{L E}(\%)$ \\
\hline Exploration and site preparation & 70 \\
Drilling and hydraulic fracturing & 59 \\
Extraction, treatment and preparation & 100 \\
Distribution & 100 \\
Operation of power plant & 100 \\
\hline
\end{tabular}

\subsubsection{Gender equality}

The gender equality (GE) index for the UK oil and gas industry, of which shale gas would be an integral part, is estimated at -0.93 , reflecting the fact that the workforce is almost entirely male. Thus, the UK oil and gas sector is characterised by a very high gender inequality. Among the countries considered (Table 5 ), Canada has the highest gender equality $(-0.58)$, followed by Norway $(-0.62)$, the US $(-0.70)$ and Australia $(-0.76)$. Nevertheless, the GE values are negative for all the countries indicating that male dominance is commonplace in the oil and gas industry. Shale gas could help to address this issue by providing new opportunities for female workers to enter the industry, but this may be limited by the availability of qualified female staff. However, if specialised workforce were to be imported from the US (as anticipated, see the previous section) which has a better GE than the UK, it may be possible to redress the gender balance but this would only be effective if the majority of staff to be imported from the US were female.

\subsection{Health and safety: worker injuries}

The estimates for worker injuries, obtained using eqn. (4) and data in Table 6, are given in Table 17. As indicated, the worker injuries in the life cycles of shale and conventional gas electricity, are the lowest ( $\mathrm{WI}=0.53$ and 0.54 , respectively) out of all the electricity options considered, suggesting that they are the safest option from a workforce perspective. However, the injuries in the supply chain of LNG electricity are much higher (four times). The reason for this is that most of LNG is 
imported to the UK from Qatar where natural gas is extracted offshore and injury rates are higher than in the UK. In addition, the contribution of LNG transport is high (52\%) because of the number of shipments needed to sustain a CCGT power plant over its lifespan.

The worst option overall is hydroelectricity, with 28 times larger WI than electricity from shale gas (Table 17). These are mainly incurred during the construction and demolition of the power plant, and are related to the relatively high injury rates in the construction sector.

Table 17: Worker injuries in the life cycle of shale gas and other electricity options ${ }^{\mathrm{a}}$.

\begin{tabular}{lc}
\hline Technology & Worker injury rate, WI (injuries/TWh) \\
\hline Shale gas & 0.53 \\
Conventional gas & 0.54 \\
LNG & 2.10 \\
Coal & 4.50 \\
Nuclear & 0.59 \\
Hydro & 14.59 \\
Solar PV & 4.84 \\
Offshore wind & 2.30 \\
Biomass & 2.98 \\
\hline a The results for shat
\end{tabular}

${ }^{\mathrm{a}}$ The results for shale gas, LNG and hydro are estimated in this work. The results for the other electricity options are sourced from Stamford and Azapagic (2012).

\subsection{Nuisance}

\subsubsection{Noise}

As shown in Figure 2, the noise levels from shale gas activities in the UK are predicted to be in the range of $38-57 \mathrm{~dB}$ at a distance of $15 \mathrm{~m}$ from the site (Arup, 2014a). This is lower or comparable to common noises, such as traffic, washing machines or typical office noise, and is well below the hearing damage threshold. However, prolonged exposure would lead to adverse effect on hearing (Hays et al., 2016), although the activities which produce the most noise are temporary (hydraulic fracturing), so adverse effects to hearing are unlikely.

Figure 2 also indicates that the noise values predicted for the UK are half the actual levels measured in the US (77-104 dB) at the same distance of $15 \mathrm{~m}$ (MDE and DNR, 2015; Vondra, 2014). This is likely because the UK noise predictions are for exploration drilling and hydraulic fracturing, while the US values are from full scale projects. Equipment and activities used in exploration/preliminary drilling and hydraulic fracturing will be smaller than that used in full scale projects and consequentially, the noise levels will be lower. However it is uncertain whether the same size and capacity equipment used in the US will be used in the UK when commercial drilling begins. Therefore, these predicted values should be treated with caution.

The distance from a well site will also have significant impacts on the level of noise experienced. The distance from residential areas is uncertain as the UK currently has no legislation on setback distances (Cave, 2015). Proposed sites, such as Roseacre Wood and Kirby Misperton, are $2 \mathrm{~km}$ and $635 \mathrm{~m}$ from residential areas (Arup, 2014b; Ross, 2015) and at these distances the noise levels (calculated using the inverse square law) would not exceed 22 and $32 \mathrm{~dB}$, respectively. UK wind farms and wind turbines have no legislation for setback distances either, but a distance of 350 $\mathrm{m}$ is recommended, increasing up to $3 \mathrm{~km}$ for large turbines and farms (Cave, 2013). At these distances, shale gas noise levels would reduce to 8-37 dB and up to $19 \mathrm{~dB}$, respectively. The US legislates setback distances of $150-300 \mathrm{~m}$ (Cave, 2015) for shale gas wells, which would correspond to noise levels of 19-44 dB and 6-35 dB. These noise levels are comparable with breathing and quiet conversations (Figure 2), so it is unlikely that at these distances noise generated by shale gas development would cause major disruptions or adverse impacts on hearing and general wellbeing (stress, anxiety, sleep). However, these estimates are based on predicted noise levels, emphasising the need for accurate predictions as they can impact on what noise reduction measures are taken. 


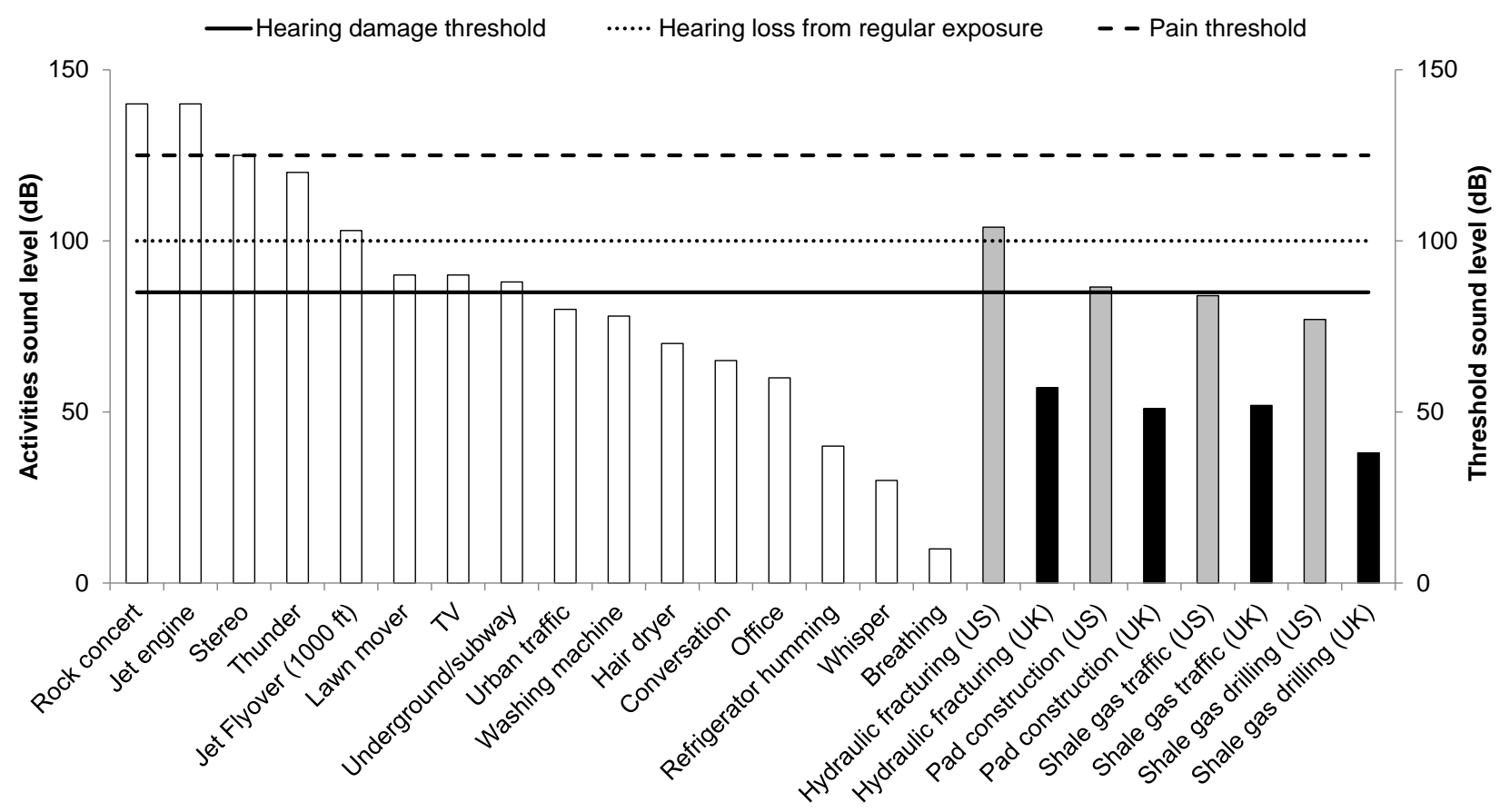

Figure 2: Predicted noise levels for shale gas activities in the UK (Arup, 2014a; MDE and DNR, 2015; Vondra, 2014) in comparison with the actual shale gas noise levels in the US (MDE and DNR, 2015; Vondra, 2014) and some other common sounds.

[UK shale-gas activities are represented by black bars and related US activities by grey bars.]

\subsection{2. $\underline{\text { Traffic }}$}

The impact of shale gas development on traffic will depend on the type of road. Based on the predicted congestion reference flow (CRF) for urban roads, estimated using eqn. (5) and data in Tables S1 and S2 in the SI, the maximum increase in traffic volume would range from $3 \%$ for urban motorways with dual carriageway (14.6 m wide) to $30 \%$ for the single-lane carriageways $(6.1 \mathrm{~m})$. This represents the maximum impact, i.e. if all the trucks were to arrive within an hour of one another during peak hour. For rural roads, truck traffic would increase congestion by $3 \%$ and $12 \%$ for dual and single carriageways, respectively. The reason for the lower impact on rural roads and single carriageways is because they are typically busier and more congested during peak hour due to commuting.

In either case, it is important that the increase in traffic and congestion is managed to minimise the impact on local communities. To reduce strain on roads, routes should be selected specifically to avoid busy lanes and peak hours. This is also important for reducing noise, impacts on air quality and road accidents (Graham et al., 2015). Residents living close to roads identified as potential routes for shale gas transport activities should also be consulted to ensure that the abovementioned impacts related to transport are minimised.

\subsection{Public perceptions}

\subsubsection{Public support}

As indicated in Table 7, the average support for shale gas across the studies is the lowest (together with coal) and the opposition second highest (after coal). However, the number of people who are unsure about their opinion of shale gas is also high, sharing the second place with LNG (after coal). This reduces the estimated public support index (PSI) since the percentage in support or opposition is also reduced. These are the reasons that shale gas has the lowest PSI of only $5.6 \%$, just after coal with $-7 \%$ (Table 18). Solar PV, hydro and wind enjoy the highest public support $(65 \%-72 \%)$. The high percentage of 'unsure' responses also highlights the need for increasing public knowledge and understanding of shale gas; for further discussion of this topic, see the next section. 
Table 18: Estimated public support for different electricity technologies

\begin{tabular}{lc}
\hline Technology/energy source & Public support index, PSI (\%) \\
\hline Shale gas & 5.6 \\
Conventional gas & 34 \\
LNG $^{\mathrm{a}}$ & 15 \\
Coal & -7 \\
Nuclear & 9 \\
Hydro & 72 \\
Solar PV & 75 \\
Offshore wind & 65 \\
Biomass & 57 \\
\hline
\end{tabular}

a Survey considered support on the export of LNG in the US.

\subsubsection{Media impact}

With a media impact index of 0.65 (estimated by eqn. (6)-(9) and data in Table S3), NGOs have by far the largest potential to influence public opinion about shale gas. Government bodies and academic organisations considered in this work have a score of 0.35 , while shale gas operators score a zero. This is not to say that operators have no presence on social media sites or followers, but in comparison to NGOs and the other parties considered, their impact through social media appears negligible. This large difference in the presence means that people are able to see more messages and information put forward by NGOs, thereby potentially skewing how the issues surrounding shale gas are framed. As over $50 \%$ of the UK population use social media (ONS, 2016; Statista, 2017b), the public's impression of shale gas is thus more likely to be shaped far more effectively by NGOs than any other stakeholders.

\subsection{Local communities}

\subsubsection{Spending on local or domestic suppliers}

As can be seen in Table 8 , the percentage spending on local or domestic suppliers $P_{L S}$ is estimated (by eqn. (10)) at $100 \%$ for all equipment and services, except for specialised hydraulic fracturing equipment, drilling rigs and directional drilling. Thus, the total potential spending on local or domestic suppliers for shale development in the UK is estimated to range from $37.9 \%$ to $47 \%$ of the total spend of $£ 32.12 \mathrm{bn}$, equivalent to $£ 12.17-15.12 \mathrm{bn}$. The remaining $17 \mathrm{bn}$ will be spent for the specialised equipment that will have to be imported from overseas, mostly probably the US (Calfrac, 2015; Lewis et al., 2014).

The spending will be spread throughout a 15 year period, the time required for the UK shale gas industry to reach maturity from the commencement of commercial drilling (Lewis et al., 2014). Based on this, the spending on local or domestic suppliers would average out at $£ 0.81-£ 1$ billion per year, thereby boosting the UK's GDP by $0.04 \%-0.05 \%$ (based on the 2015 GDP (Statista, 2017a)). This could be increased via research and development into hydraulic fracturing and directional drilling, with the aim of developing UK designed and manufactured technology. However, it should be noted that in reality spending would not be evenly distributed throughout the 15 years, but it would increase with drilling rates to a maximum (corresponding to peak drilling) and then decline.

\subsubsection{Direct community investment}

It has been reported that communities affected by shale gas could receive up to £2.1 billion, through the combination of the community charter and the shale gas wealth fund (HM Treasury, 2016; UKOOG, 2013). According to the community charter, local communities will receive $£ 100,000$ per well site and $1 \%$ of revenue from the sales of shale gas produced, or $£ 1.1$ billion combined total (Cronin, 2013; UKOOG, 2013), both of which are considered to be a direct community investment. Previous work estimated that local communities could receive $£ 351,000$ - 
$£ 665,000$ per well from the community charter (Cooper, 2017), which would result in $£ 470,000$ $£ 890,000$ in investment for communities per year for each well site ${ }^{1}$.

The wealth fund is a fund paid for by shale gas tax revenue (HM Treasury, 2016), but it is uncertain what percentage of this tax revenue will go towards the fund. In addition to shale gas, communities close to power plants also benefit $£ 4.1-£ 10$ million per year from investments into sponsored events and other community activities (npower, 2017). Thus, over the whole life cycle of shale gas electricity, the total direct community investment $P_{L I}$ estimated using eqn. (11) and Table 9, is in the range of $£ 4.6-£ 10.9$ million per year. This represents $0.73 \%-2.23 \%$ of the total annual revenue generated by shale gas and power plant operators. This is arguably a small percentage of their revenue and more could be given back to local communities. Who exactly will receive the money is uncertain as the community charter and wealth fund do not specify whether individual households or local councils or both will be the beneficiaries.

However, even a moderate contribution to communities is likely to be beneficial at a time when many local councils are facing budget cuts from central government. For example, Lancashire County Council - one of the main UK councils facing shale gas development activity - had a net 2015/16 budget of $£ 726.7$ million and must save $£ 152$ million by 2018 (Lancashire County Council, 2015). Similarly, Salford City Council - another area where exploration of shale gas is proposed had a budget for $2015 / 16$ of $£ 207.7$ million and has been forced to reduce expenditure by over $£ 149$ million since 2010/11 (Salford City Council, 2015).

\subsection{Infrastructure and resources}

\subsubsection{Diversity of fuel supply}

Shale gas is a completely indigenous fuel for the UK. Hence, its diversity of fuel supply (DSF), estimated according to eqn. (12) and data in Table 10, is equal to 1, denoting full self-sufficiency (Table 19). Therefore, if it were to displace gas imports in the UK gas mix, energy security would increase. For that reason, the DSF is higher for the scenario assuming high rather than low shale gas penetration in the gas mix (0.92 vs 0.82 ); see Table 20 . However, it should be noted that the DFS decreases for both in comparison to the present gas mix (0.94). The reason for this is twofold. Firstly, domestic gas production decreases in 2030, from the current 46.6 billion cubic metres $(\mathrm{bcm})$ to $45.8 \mathrm{bcm}$ in the high-shale scenario and $22.7 \mathrm{bcm}$ in the low-shale scenario. Secondly, there is a reduction in the number of countries exporting gas to the UK (three in 2030 as opposed to four at present).

When the impact on electricity is considered, using data in Table 11, the mix with more shale gas has a higher DFS (0.93 vs 0.90$)$, following the trend from the gas mix. However, unlike the gas mix, the DFS of the 2030 electricity mix improves on the DFS of the current mix (0.90); see Table 20. However, this is primarily due to the decline in coal generation and the increase in renewable capacity, which also has the maximum DFS score (Table 19).

Therefore, these results suggest that the DSF and the related security of supply of the gas mix are likely to remain unaffected or deteriorate in the future, depending on the amount of shale gas produced. On the other hand, the energy security of the future electricity mix is likely to improve regardless of shale gas. Consequently, shale gas does not present a notable opportunity for increased energy security, unless the volume produced increases significantly above current predictions.

\footnotetext{
${ }^{1}$ A well site consists of ten well pads, with each pad containing four horizontal wells; 40 wells in total. The lifespan of well is 30 years.
} 
Table 19: Diversity of fuel supply (DFS) for different fuel sources used to generate electricity in the UK for the present (2012) situation and future (2030) scenarios.

\begin{tabular}{lcc}
\hline Fuel & DFS (-) & \\
& 2012 & 2030 \\
\hline Shale gas & 1.00 & 1.00 \\
Conventional gas (UK North Sea) & 1.00 & 1.00 \\
Conventional gas pipeline imports $_{\text {Conventional gas liquefied natural gas imports }}$ & 0.38 & 0.36 \\
Coal $^{\mathrm{a}}$ & 0.04 & 0.04 \\
Nuclear $^{\mathrm{a}}$ & 0.86 & 0.86 \\
Hydro $_{\text {Offshore wind }}$ & 0.85 & 0.85 \\
Solar PV & 1.00 & 1.00 \\
Biomass $^{\mathrm{a}}$ & 1.00 & 1.00 \\
${ }^{\mathrm{a}}$ The 2030 DFS was assumed to be the same as in 2012 due to a lack of data on future supply mix. & 1.00 & 1.00 \\
\end{tabular}

Table 20: Diversity of fuel supply (DFS) score of the different gas and electricity mix scenarios considered in this work.

\begin{tabular}{ll}
\hline Scenario & DFS (-) \\
\hline 2012 gas mix & 0.94 \\
2030 gas mix (high shale gas) & 0.92 \\
2030 gas mix (low shale gas) & 0.82 \\
2012 electricity mix & 0.90 \\
2030 electricity mix (high shale gas) & 0.93 \\
2030 electricity mix (low shale gas) & 0.90 \\
\hline
\end{tabular}

\subsubsection{Wastewater treatment}

Previous studies on shale gas wastewater have focused on determining its complex composition (high salinity, total dissolved solids and chemicals) and the issues this causes for treatment facilities (Akob et al., 2016; Cooper et al., 2016; Parker et al., 2014). However, no studies have attempted to quantify the strain it could have on the ability of treatment facilities to treat wastewater produced during shale gas exploitation. As mentioned in Section 2.6.2, considering this is important as exceeding the capacity of existing wastewater treatment facilities could cause difficulties to communities, including the temporary shutdown of treatment plants, discharge of inadequately treated water into the environment and related nuisance and human health impacts.

The amount of wastewater produced over a well's lifespan ranges widely, from $871-75,000 \mathrm{~m}^{3}$ (see Table 12). In order to transport it from the well site to the treatment facility, tankers $\left(21-43.9 \mathrm{~m}^{3}\right)$ will be needed (Study Hills, 2012). This will require 19-3606 truck trips, contributing to an increase in traffic near the treatment plants and the well site. However, as mentioned earlier, wastewater shipments are not included in the estimation of traffic congestion due to the uncertainties in the volume of water generated and the possibility of scheduling the shipments outside peak hours. Onsite treatment of wastewater could further mitigate the impact of wastewater transport on congestion, but would also increase the capital and operating cost of the well.

In terms of strain on treatment facilities, depending on the capacity of the nearest suitable treatment plant, this work estimates that it would take between 0.02 to 97.35 hours to treat the total volume of wastewater produced by a well (

Table 13). This would increase the pressure on facilities, especially as they are in continuous operation 24 hours a day. It will also affect storage capacity at facilities, as the wastewater cannot be treated in one go (due to complex composition) without overloading the facilities during normal operation. One way of managing wastewater treatment is to spread out deliveries over the well's lifespan of 30 years. The rate at which wastewater returns to the surface is not constant, with the majority of injected fluid resurfacing within the first month of well completion. Up to $40 \%(10,000$ $\mathrm{m}^{3}$ ) of the injected fluid resurfaces, which would require 481 tankers to transport, representing the maximum in wastewater production and tanker trips. When spread out over a month, a maximum 
of 18 tanker trips to transport $357 \mathrm{~m}^{3}$ of wastewater each day would be needed. This corresponds to $0.1-4 \%$ of the capacity of the treatment facilities (

Table 13). However, this is the impact of one well so that the 4000 wells that could be drilled in the UK (Lewis et al., 2014), could put enormous strain on treatment facilities. Also, the wastewater has a complex composition which is beyond the capability of most facilities. Therefore, shale gas wastewater will likely increase the potential of wastewater not being properly treated, potentially leading to public nuisance and health issues.

\subsubsection{Land use}

As shown in Figure 3, the Bowland-Hodder shale play spans major cities and towns, including Liverpool, Manchester and York, while Leeds and Leicester are located close by. This reduces the land Retrieved from for drilling as there could be strong opposition to shale gas development close to urban areas.

The shale play also overlaps with many areas of special value and interest (Figure 4). These include the Peak District and North York Moors National Parks and areas of outstanding natural beauty (Forest of Bowland, Nidderdale and Howardian Hills). Sites of cultural importance also overlap, or are nearby, including World Heritage sites (Saltaire and Liverpool - Maritime Mercantile City) and English Heritage sites (Goodshaw Chapel, Sandbach Crosses, Roche Abbey). However, it is local nature reserves that will be the most affected, as can be seen in Figure 4. Consequently, it is likely that shale gas operators could experience stronger opposition and resilience from antishale activists and conservationists due to the importance of such sites.

Therefore, the area Retrieved from and suitable for shale gas development will likely be limited to a small number of sites, which could amplify impacts such as noise, traffic and pollution. Similar conclusions were drawn by Clancy et al. (2017) who found that, depending on setback distances, a large proportion (74\%) of land will be unsuitable for drilling.

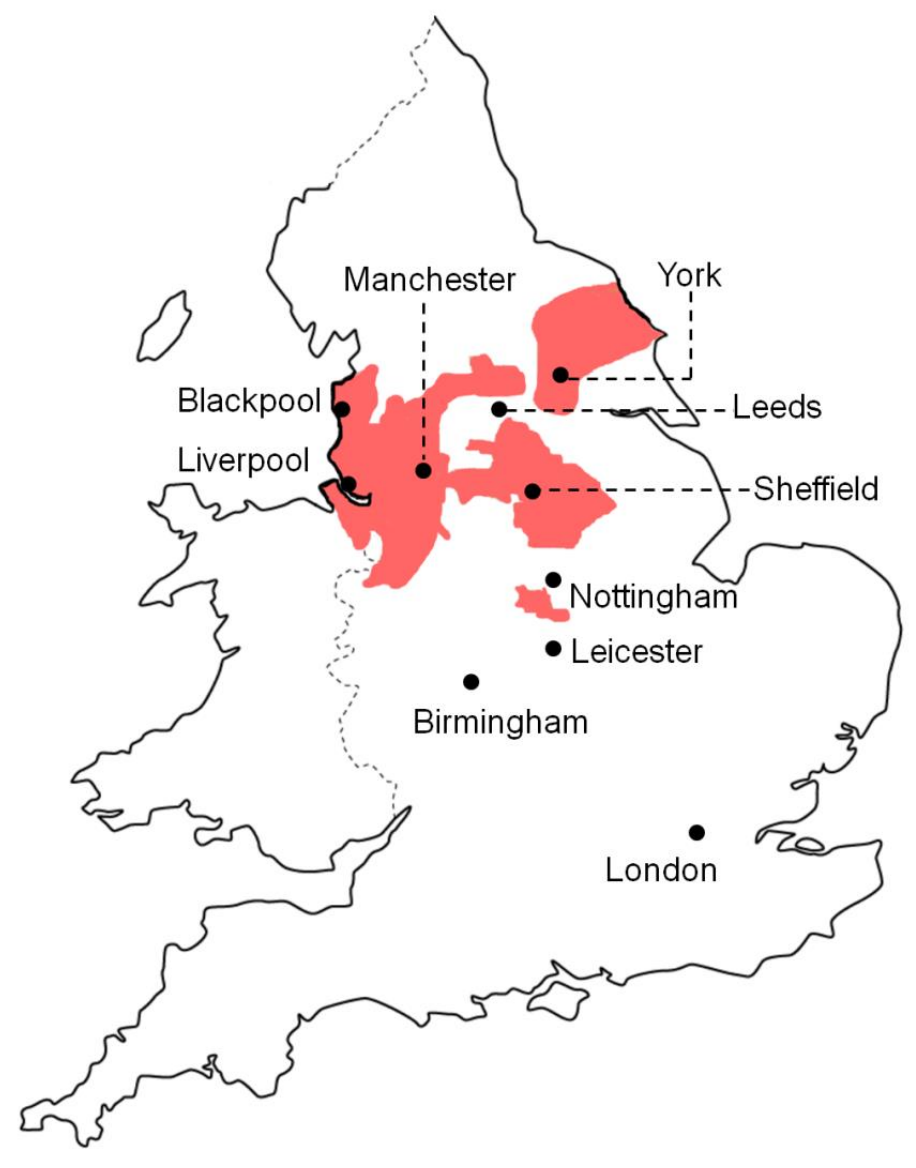

Figure 3: Major cities and towns in the vicinity of the Bowland-Hodder shale play (Andrews, 2013; Google Earth, 2015).

[The shale play is shown in red.] 


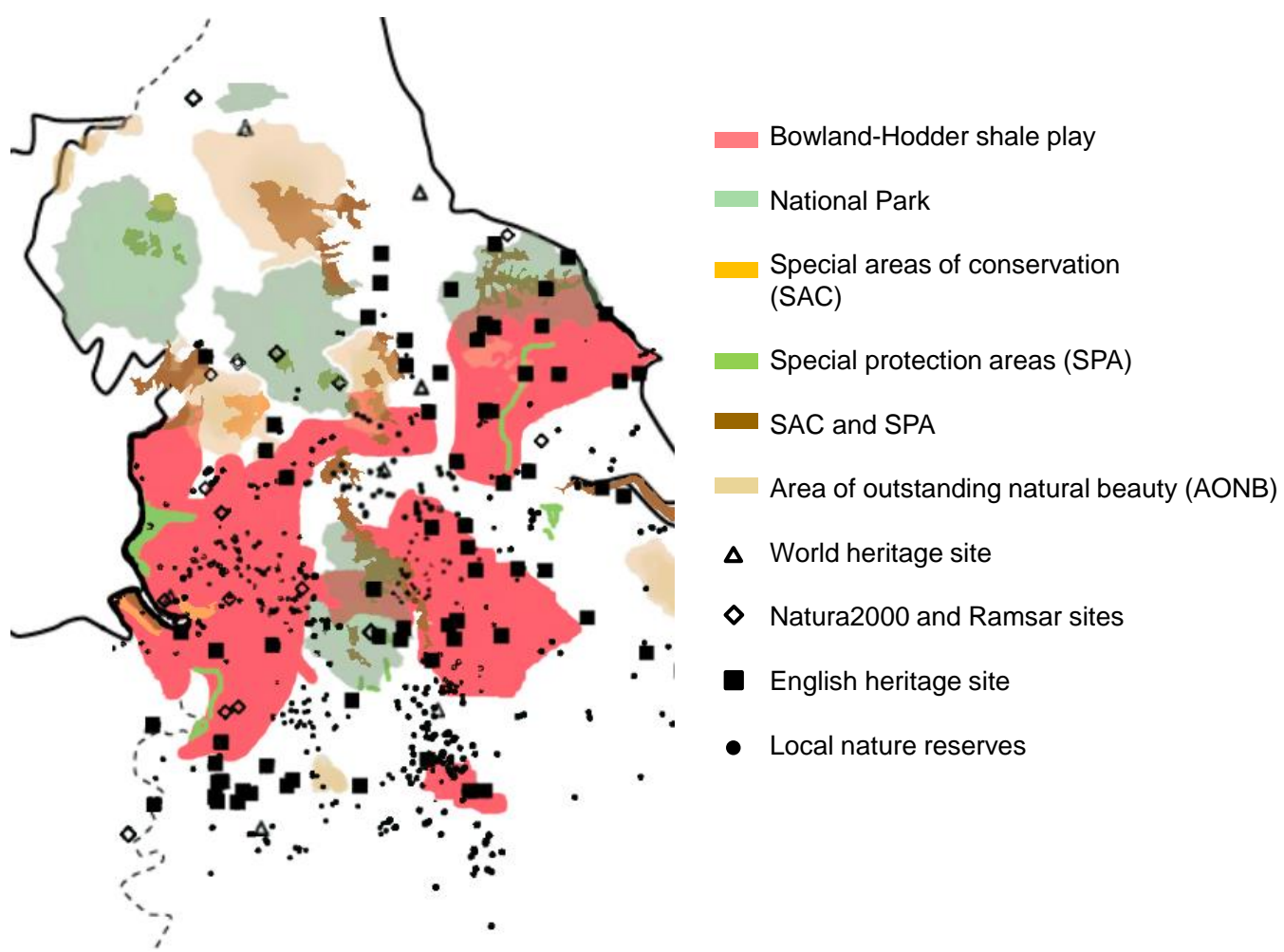

Figure 4: Map of Bowland-Hodder shale play and areas/sites of special value and importance (Andrews, 2013; National Parks, 2013; Natural England, 2013; Google Earth, 2015).

\subsubsection{Regulatory resources}

A well with a production lifespan of 30 years would require a minimum of 40 inspections over its lifespan. Based on this and the 4000 wells expected to be drilled, the UK shale gas industry would require a minimum of 160,000 inspections. Therefore, it is important that the regulatory system in place is adequately staffed to be able to cope with the large number of inspections required. As one full time inspector should be in charge of no more than 300 wells, this would result in a minimum requirement of 14 full time inspectors needed for the UK shale gas industry (Western Organization of Resource Councils, 2013). Additional support staff will also be needed, such as administrative personnel.

Whilst this number of inspectors seems low, the US experience has shown that the large well-toinspector ratio overwhelms the capability of regulatory staff, with inspection-to-inspector ratios in the range 270-2450. This has resulted in many wells failing to meet the minimum requirement of one inspection per year, in turn leading to violations slipping through without detection (Earthworks, 2012a; Earthworks, 2012b). At the time of writing, BEIS, the relevant regulatory body, has a total of 63 environmental regulation staff (technical and non-technical), including seven inspectors, and carries out 60-150 inspections per year on the UK continental shelf. This equates to 8.6-21.4 inspections per inspector (DECC, 2011). The EA and HSE would also be involved in regulating different stages of shale gas extraction. If or when the shale gas industry takes off in the UK, the inspection ratio will increase significantly and, therefore, it is imperative that staffing numbers increase to keep up with demand. However, it should be noted that training of regulators is a key issue associated with regulation. In the US, a training initiative was launched to train regulators and policy makers, but this initiative is being partially funded by ExxonMobil and General Electric (Olson et al., 2012). This may cause concern for the general public as it could be seen as a form of self-regulation and undermine the trust in regulation. Therefore it is important for regulatory staff training and education to be funded and run by neutral bodies, such as government agencies. 


\section{Conclusions}

This paper has considered the social sustainability of developing shale gas in the UK and using it to generate electricity. In total, 14 indicators have been used to analyse impacts on employment, health and safety, nuisance, public perceptions, community impacts and infrastructure and resources.

The results suggest that the main benefits that could arise from shale gas production and utilisation stem mostly from job creation and financial gains for communities impacted by development. Overall, a significant number of jobs could be created; however, the majority of these are temporary, contributing little to direct employment. Despite this, the long-term jobs created are well paid, particularly in the gas production, gas distribution and electricity generation; this is in line with the rest of the oil and gas sector. Also, a large proportion of the jobs created could be sourced from local labour. Therefore, to maximise the benefits created through employment, it is important to source labour locally or domestically. Another way of maximising employment gains is to train personnel for roles which require specialised labour.

The other main benefit of shale gas development is related to financial gains to communities. Communities stand to benefit from direct investment through funds and charters, as well as increased trade for local businesses. This would primarily provide boosts to local economies in areas affected by shale gas development. However, it is important that the distribution of the investment into communities is equitable and transparent, to ensure their use to the best effect for all affected by the development, while minimising the potential for mismanagement of funds.

Additional benefits of shale gas are related to health and safety. In comparison to other electricity options, it is the safest industry from a workforce perspective, as it has the lowest worker injury rates. This is because the jobs across the life cycle of shale gas are in sectors which have lower accident rates than those involved in the stages of other electricity options, such as construction and mining. Furthermore, as shale gas is a completely indigenous fuel source, it could help increase (or maintain) energy security in the UK. However, this will depend on the volume produced and on what the future energy mix is made up of; increase in renewables and drop in fossil fuels would also improve energy security of UK electricity.

One of the disadvantages of shale gas is a high potential for inadequate treatment in wastewater facilities, which could release substances harmful to humans and the environment into water bodies. This is due to the large volume of wastewater produced by a well and the large number of wells expected to be drilled, coupled with the complex composition of wastewater, with high salinity and a cocktail of chemicals. The development of shale gas could also overwhelm regulatory bodies, as at least 160,000 inspections of wells would be required over a period of over 30 years.

Furthermore, there could be land conflict over development because the main shale play spans many sites of special value and interest. This will necessitate a concentration of development in specific areas, which could lead to an amplification of the impacts from noise, traffic and wastewater. The use of heavy machinery and the need to bring in and out equipment and materials by trucks will cause disruption to those who live close to well sites and along roads being used for transport. The activities which generate the most noise and traffic are temporary, but if development is concentrated, it could lead to prolonged periods of drilling, hydraulic fracturing and heavy traffic. This would do little to improve the UK public's opinion of shale gas, which is currently not favourable.

Therefore, if shale gas was to be developed in the UK, it is imperative that appropriate mitigation measures are in place to reduce the societal (and other) impacts while also developing strategies to maximise the benefits that could be created. Mitigation measures include: minimising noise through housing diesel powered generators in acoustic sheds and using acoustic fencing around the well sites; using roads during non-peak hours; onsite wastewater treatment via membrane filtration or reverse osmosis prior to delivery to treatment plant; better balance of information presented about shale gas and more effective communication by those involved in developing shale gas; communication strategies which build trust between developers and communities 
affected and the general public. Measures to maximise the benefits include: specialised skills and training centres for shale gas extraction; research and development into hydraulic fracturing and directional drilling technology; consultation with communities on how charters/funds should be distributed and spent equitably.

Overall, there are many social issues which need to be addressed regarding shale gas development in the UK. However, there are a number of impacts not considered in this work including geopolitics, long-term health impacts and insurance. Such impacts should be the focus of future studies. Also, outside the UK, shale gas is being produced in the US, Canada and China, so lessons learned there in terms of impacts and community benefit strategies could too be the focus of future studies.

\section{Nomenclature}

$A A D T$ the annual average daily traffic flow (vehicles/day)

$A A W T$ the annual average weekday flow (vehicles/day)

$C$ exporting country

C total number of exporting countries

CAP maximum vehicle capacity per road lane (vehicles/day)

$C R F$ congestion reference flow (vehicles/day)

$D E \quad$ total direct employment generated in the life cycle of shale gas along the supply chain (person-years/kWh)

$D E_{i} \quad$ number of jobs created in life cycle stage $i$ (persons)

DFS diversity of fuel supply mix (-)

$E_{i} \quad$ employment in life cycle stage $i$ (person-years/TWh)

FW percentage of female workforce (\%)

GE gender equality index (-)

$i \quad$ life cycle stage

I total number of life cycle stages

$j \quad$ type of social media metrics (e.g. tweets, 'likes', etc.)

$J \quad$ total number of social media metrics

$L \quad$ number of lanes on the road (-)

LE number of employees that could be hired from the local community (persons-years/TWh)

$L I_{A} \quad$ annual investment in and donations to the local community (£/year)

$m \quad$ social media platform (-)

$M \quad$ total number of social media platforms (-)

MIIs total media impact index of stakeholder $s(-)$

$n_{s, j} \quad$ value of social media metrics $j$ (e.g. number of tweets, 'likes', etc.) by stakeholder $s(-)$

$n_{i(\max )}$ the highest value of social media metrics $j(-)$

$P_{i m} \quad$ proportion of fuel consumption from imported resources (-)

$P_{i m, c} \quad$ proportion of fuel imports supplied by exporting country c

$P_{\text {in }} \quad$ proportion of fuel consumption from domestic resources (-)

$P k D$ the directional split of traffic flow during peak hours (-)

$P k F \quad$ proportion of daily traffic flow during peak hours (-)

$P_{L E} \quad$ proportion of employees that could be hired from the local community (\%)

$P_{L I} \quad$ percentage of direct investment into the local community (\%)

$P_{L S} \quad$ percentage of total spending spent on local or domestic suppliers (\%)

$P_{s} \quad$ total presence of stakeholder $s$ on all social media platforms considered (-)

$P_{s, j} \quad$ presence of stakeholder $s$ for social media metrics $j(-)$

PSI public support index (-)

$P_{T} \quad$ total presence of all stakeholders on all social media platforms considered (-)

$P_{\text {tot }} \quad$ total amount of electricity generated over the lifetime of power plant (TWh)

$r_{i} \quad$ average annual injury rate (injuries/person-years)

$R_{T} \quad$ total annual revenue (£/year)

$S \quad$ stakeholder (-)

$S_{L S} \quad$ total spending on local or domestic suppliers $(£)$

$S_{T} \quad$ total potential expenditure on suppliers $(£)$

TE total number of employees needed (persons-years/TWh) 
$t_{i} \quad$ duration of employment in life cycle stage $i$ (years)

$W_{f} \quad$ width factor - width of road lanes relative to a standard width of $3.65 \mathrm{~m} \mathrm{(-)}$

WI number of worker injuries (injuries/TWh)

\section{Acknowledgements}

This work was funded by the UK Engineering and Physical Sciences Research Council (grant no. EP/K011820/1) and the University of Manchester's Alumni Donor Society. This funding is gratefully acknowledged.

\section{References}

Adamus, W. and Florkowski, W. J. 2016. The evolution of shale gas development and energy security in Poland: Presenting a hierarchical choice of priorities. Energy Research and Social Science, 20, 168-178.

Adgate, J. L., Goldstein, B. D. and McKenzie, L. M. 2014. Potential public health hazards, exposures and health effects from unconventional natural gas development. Environmental Science and Technology, 48, 8307-8320.

Akob, D. M., Mumford, A. C., Orem, W., Engle, M. A., Klinges, J. G., Kent, D. B. and Cozzarelli, I. M. 2016. Wastewater disposal from unconventional oil and gas development degrades stream quality at a West Virginia injection facility. Environmental Science and Technology, 50, 55175525.

AMEC. 2013. Strategic Environmental Assessment for Further Onshore Oil and Gas Licensing. Department of Energy and Climate Change. London.

Andrews, I. J. 2013. The Carboniferous Bowland Shale gas study: geology and resource estimation. British Geological Society. London, UK.

Arup. 2014a. Environmental statement: Appendix P- Noise. Cuadrilla Elswick Ltd. Manchester, UK. Retrieved from: http://www.cuadrillaresources.com/our-sites/locations/roseacre-wood/.

Arup. 2014b. Temporary Shale Gas Exploration at Roseacre Wood, Lancashire- Environmental Statement- Volume 1. Cuadrilla Elswick Ltd. Preston, UK. Retrieved from: http://www.cuadrillaresources.com/our-sites/locations/roseacre-wood/.

Ashmoore, O., Evensen, D., Clarke, C., Krakower, J. and Simon, J. 2016. Regional newspaper coverage of shale gas development across Ohio, New York, and Pennsylvania: Similarities, differences, and lessons. Energy Research and Social Science, 11, 119 - 132.

Barber, J. R., Burdett, C. L., Reed, S. E., Warner, K. A., Formichella, C., Crooks, K. R., Theobald, D. M. and Fristrup, K. M. 2011. Anthropogenic noise exposure in protected natural areas: estimating the scale of ecological consequences. Landscape Ecology, 26, 1281-1295.

Barber, J. R., Crooks, K. R. and Fristrup, K. M. 2010. The costs of chronic noise exposure for terrestrial organisms. Trends in Ecology and Evolution, 25, 180-189.

Behrer, A. P. and Mauter, M. S. 2017. Allocating Damage Compensation in a Federalist System: Lessons from Spatially Resolved Air Emissions in the Marcellus. Environmental Science and Technology, 51, 3600-3608.

BHA. 2017. Hydro facts [Online] Wimborne, UK: British Hydro Association (BHA). Retrieved from: http://www.british-hydro.org/hydro facts.html.

Boudet, H., Clarke, C., Bugden, D., Maibach, E., Roser-Renouf, C. and Leiserowitz., A. 2013. "Fracking" controversy and communication: Using national survey data to understand public perceptions of hydraulic fracturing. Energy Policy, 65, 57-67.

Broderick, J., Anderson, K., Wood, R., Gilbert, P. and Sharmina., M. 2011. Shale gas: an updated assessment of environmental and climate change impacts. Tyndall Centre for Climate Change and Research. Manchester.

Calfrac. 2015. Fracturing equipment profiles [Online] Denver, CO, USA. Retrieved from: http://www.calfrac.com/Customer-Centre/Service-Line-Equipment/Fracturing-EquipmentProfiles/index.php.

Castell, S., Charlton, A., Clemence, M., Pettigrew, N., Pope, S., Quigley, A., Shah, J. N. and Silman, T. 2014. Public Attitudes to Science 2014. Ipsos MORI. London.

Cave, S. 2013. Wind turbines: Planning and separation distances. Northern Ireland Assembly Belfast, NIR. Retrieved from: http://www.niassembly.gov.uk/globalassets/documents/raise/publications/2013/environment/12 813.pdf. 
Cave, S. 2015. Proximity of petroleum exploration wells to dwellings. Northern Ireland Assembly. Belfast NIR.

Retrieved

from:

http://www.niassembly.gov.uk/globalassets/documents/enterprise-trade-and-

investment/hydraulic-fracturing/20150304-assembly-research---petroleum-wells.pdf.

Christenson, D. P., Goldfarb, J. L. and Kriner, D. L. 2017. Costs, benefits, and the malleability of public support for "Fracking". Energy Policy, 105, 407-417.

Clancy, S. A., Worrall, F., Davies, R. J. and Gluyas, J. G. 2017. An assessment of the footprint and carrying capacity of oil and gas well sites: The implications for limiting hydrocarbon reserves. Science of The Total Environment, In Press- Corrected Proof.

Clark, C., Burnham, A., Harto, C. and Horner, R. 2013. Hydraulic fracturing and shale gas production: Technology, impacts, and regulations. Argonne National Laboratory. Oak Ridge, TN, USA. Retrieved from: http://www.afdc.energy.gov/uploads/publication/anl hydraulic fracturing.pdf.

ComRes. 2015. Greenpeace fracking survey. ComRes. London, UK. Retrieved from: http://www.comres.co.uk/polls/greenpeace-fracking-survey/.

Cooper, J. 2017. Life cycle sustainability assessment of shale gas in the UK. PhD thesis, The University of Manchester.

Cooper, J., Stamford, L. and Azapagic, A. 2014. Environmental impacts of shale gas in the UK: Current situation and future scenarios. Energy Technology, 2, 1012-1026.

Cooper, J., Stamford, L. and Azapagic, A. 2016. Shale Gas: A Review of the Economic, Environmental, and Social Sustainability. Energy Technology, 4, 772-792.

Cooper, S. 2015. Breaking - 1,000 jobs on way as Knottingley Power Station plans approved. Pontefract and Castleford Express, 10 March 2015, Retrieved from from: http://www.pontefractandcastlefordexpress.co.uk/news/breaking-1-000-jobs-on-way-asknottingley-power-station-plans-approved-1-7148866.

Cronin, K. 2013. Community engagement charter oil and gas from unconventional reservoirs. UK Onshore Oil and Gas (UKOOG). London, UK. Retrieved from: https://www.gov.uk/government/uploads/system/uploads/attachment data/file/256360/Publicat ion UKOOG communityengagementcharterversion6.pdf.

Cuadrilla Resources. 2017. Our Lancashire sites [Online] Preston, UK. Retrieved from: http://www.cuadrillaresources.com/our-sites/lancashire-sites/.

Cunningham, N. 2014. Why the debate over US LNG expoerts has been won. oilprice.com [Online]. Retrieved from: http://oilprice.com/Energy/Natural-Gas/Why-the-Debate-Over-U.S.LNG-Exports-Has-Been-Won.html.

Czebiniak, M. 2014. Women find careers in energy as downstream, petchems see growth. Pittsborgh Post-Gazette, August 12, 2014, Retrieved from from: http://powersource.postgazette.com/powersource/companies/2014/08/12/Women-of-shale/stories/201408120004.

DECC. 2011. Offshore oil and gas in the UK: an independent review of the regulatory regime Department of Energy and Climate Change (DECC). London, UK. Retrieved from: https://www.gov.uk/government/publications/offshore-oil-and-gas-in-the-uk-independentreview-of-the-regulatory-regime.

DECC. 2013a. Updated energy and emissions projections 2013. Department of Energy and Climate Change (DECC). London, UK. Retrieved from: https://www.gov.uk/government/uploads/system/uploads/attachment data/file/239937/uep 20 13.pdf

DECC. 2013b. UK energy in brief 2013. Department of Energy and Climate Change (DECC). London, UK. Retrieved from: https://www.gov.uk/government/uploads/system/uploads/attachment data/file/224130/uk ener gy in brief 2013.PDF.

DECC. 2013c. Onshore oil and gas exploration in the UK: regulation and best practice. Department of Energy and Climate Change (DECC). London, UK. Retrieved from: https://www.gov.uk/government/uploads/system/uploads/attachment data/file/503067/Onshor e UK oil and gas exploration England Dec15.pdf.

DECC. 2014. Fracking UK shale: water. London, UK. Retrieved from: https://www.gov.uk/government/uploads/system/uploads/attachment data/file/277211/Water.p df. 
DECC. 2015. DECC public attitudes tracking survey: Wave 15. Department of Energy and Climate Change (DECC). London, UK. Retrieved from: https://www.gov.uk/government/collections/public-attitudes-tracking-survey.

EA. 2012. Guidance note: Regulation of exploratory shale gas operations. Environment Agency (EA). Bristol, UK. Retrieved from: http://www.groundwateruk.org/downloads/EA ShaleGasRegulation.pdf.

Earthworks. 2012a. Pennsylvania Department of Environmental Protection Enforcement Report: Inadequate enforcement guarantees irresponsible oil and gas development in Pennsylvania. Pennsylvania Department of Environmental Protection. Washington DC. Retrieved from: https://www.earthworksaction.org/files/publications/FINAL-PA-enforcement-sm.pdf.

Earthworks. 2012b. Pennsylvania oil and Gas Enforcement- Inspections [Online] Washington DC: Pennsylvania Department of Environmental Protection. Retrieved from: https://www.earthworksaction.org/issues/detail/pennsylvania oil gas enforcement inspection s\#.VI8Md7 U2iw.

EDF Energy. 2017. West Burton B CCGT power station [Online] Lonodn, UK: EDF Energy. Retrieved from: https://www.edfenergy.com/energy/power-stations/west-burton-b-ccgt.

Evans, A. 2016. Appeals in relation to proposed shale gas exploration works and associated monitoring works at Preston New Road and Roseacre Wood by Cuadrilla Bowland Ltd and Cuadrilla Elswicl Ltd. Kings Chambers. Manchester, UK. Retrieved from: http://www.programmeofficers.co.uk/Cuadrilla/Inquiry/LCC/LCC INQ1.pdf.

Evensen, D., Jacquet, J. B., Clarke, C. E. and Stedman, R. C. 2014. What's the 'fracking' problem? One word can't say it all. The Extractive Industries and Society, 1, 130-136.

Fontenot, B. E., Hunt, L. R., Hildenbrand, Z. L., Carlton Jr., D. D., Oka, H., Walton, J. L., Hopkins, D., Osorio, A., Bjorndal, B., Hu, Q. H. and Schug, K. A. 2013. An Evaluation of Water Quality in Private Drinking Water Wells Near Natural Gas Extraction Sites in the Barnett Shale Formation. Environmental Science and Technology, 47, 10032-10040.

Freyman, M. and Salmon, R. 2013. Hydraulic fracturing and water stress: Growing competitive pressures for water. Ceres. Boston, MA, USA. Retrieved from: http://www.ceres.org/resources/reports/hydraulic-fracturing-water-stress-water-demand-bythe-numbers.

Fullenbaum, R. F., Larson, J. W. and Dorsey, J. 2011. The Economic and Employment Contributions of Shale Gas in the United States. IHS Global Insight (USA). Washington DC.

Goodman, P. S., Galatioto, F., Thorpe, N., Namdeo, A. K., Davies, R. J. and Bird, R. N. 2016. Investigating the traffic-related environmental impacts of hydraulic-fracturing (fracking) operations. Environment International, 89-90, 248-260.

Google Earth. 2015. UK Google Earth 7.1.5.1557 Google Earth 7.1.5.1557 Google Inc.

Gosden, E. 2016. Fracking gets go-ahead in UK for first time since 2011 as North Yorkshire council approves plans. The Telegraph, 23 May 2016, Retrieved from from: http://www.telegraph.co.uk/news/2016/05/23/north-yorkshire-council-approves-fracking-plans/.

Graham, J., Irving, J., Tang, X., Sellers, S., Crisp, J., Horwitz, D., Muehlenbachs, L., Krupnick, A. and Carey, D. 2015. Increased traffic accident rates associated with shale gas drilling in Pennsylvania. Accident Analysis and Prevention, 74, 203 - 209.

Haddad, N. M., Brudvig, L. A., Clobert, J., Davies, K. F., Gonzalez, A., Holt, R. D., Lovejoy, T. E., Sexton, J. O., Austin, M. P., Collins, C. D., Cook, W. M., Damschen, E. I., Ewers, R. M., Foster, B. L., Jenkins, C. N., King, A. J., Laurance, W. F., Levey, D. J., Margules, C. R., Melbourne, B. A., Nicholls, A. O., Orrock, J. L., Song, D.-X. and Townshend, J. R. 2015. Habitat fragmentation and its lasting impact on Earth's ecosystems. Science Advances, 1, e1500052.

Hartley, P. R., III, K. B. M., Temzelides, T. and Zhang, X. 2015. Local employment impact from competing energy sources: Shale gas versus wind generation in Texas. Energy Economics, 49, $610-619$.

Hays, J., McCawley, M. and Shonkoff, S. B. C. 2016. Public health implications of environmental noise associated with unconventional oil and gas development. Science of The Total Environment, 580, 448-456.

Hendry, C. 2011. New power stations bring jobs to Yorkshire [Online] London, UK: Department of Energy and Climate Change (DECC). Retrieved from: https://www.gov.uk/government/news/new-power-stations-bring-jobs-to-yorkshire. 
HM Treasury. 2016. Shale wealth fund: consultation, London, UK.

House of Lords. 2014. The economic impact on UK energy policy of shale gas and oil. May, 2014. House of Lords: Economic Affairs Committee. London, UK. Retrieved from: http://www.publications.parliament.uk/pa/ld201314/ldselect/ldeconaf/172/172.pdf.

HSE. 2015. Statistics: Industries [Online] London, UK: Health and Safety Executive (HSE). Retrieved from: http://www.hse.gov.uk/Statistics/industry/index.htm.

HSE. 2017. Index of data tables. Health and Safety Executive (HSE): London, UK (August 2017) Retrieved from: http://www.hse.gov.uk/Statistics/tables/index.htm.

IEA. 2011. World energy outlook 2011: Are we entering a golden age of gas? . International Energy Agency (IEA). Paris, FR. Retrieved from: http://www.worldenergyoutlook.org/media/weowebsite/2011/weo2011 goldenageofgasreport.p df.

Israel, A. L., Wong-Parodi, G., Webler, T. and Stern, P. C. 2015. Eliciting public concerns about an emerging energy technology: The case of unconventional shale gas development in the United States. Energy Research and Social Science, 8, 139 - 150.

Jacquet, J. B. 2014. Review of risks to communities from shale energy development. Environmental Science and Technology, 48, 8321-8333.

Jaspal, R. and Nerlich, B. 2013. Fracking in the UK press: Threat dynamics in an unfolding debate. Public Understanding of Science, 23, 348-363.

Jaspal, R., Nerlich, B. and Lemancyzk, S. 2014. Fracking in the Polish press: Geopolitics and national identity. Energy Policy, 74, 253-261.

Jones, I. L., Bull, J. W., Milner-Gulland, E. J., Esipov, A. V. and Suttle, K. B. 2014. Quantifying habitat impacts of natural gas infrastructure to facilitate biodiversity offsetting. Ecology and Evolution, 4, 79-90.

Lancashire County Council. 2015. 2015-16 Revenue budget - Precepts and council tax - and cash limits covering report. Lancashire County Council,. Lancaster, UK. Retrieved from: http://council.lancashire.gov.uk/mgAi.aspx?ID=27315\#mgDocuments.

Lewis, C., Speirs, J. and MacSweeney, R. 2014. Getting ready for UK shale gas: Supply chain and skills requirements and opportunities. United Kingdon Onshore Oil and Gas and Ernst and Young. London. Retrieved from: http://www.ey.com/Publication/vwLUAssets/Getting ready for UK shale gas/\$FILE/EYGetting-ready-for-UK-shale-gas-April-2014.pdf.

Lutz, B. D., Lewis, A. N. and Doyle, M. W. 2013. Generation, transport, and disposal of wastewater associated with Marcellus Shale gas development. Water Resources Research, 49, 647-656.

MacLeay, I., Harris, K. and Annut, A. 2013. Digest of United Kingdom energy statistics 2013. Department of Energy and Climate Change (DECC). London, UK. Retrieved from: https://www.gov.uk/government/uploads/system/uploads/attachment data/file/279523/DUKES 2013 published version.pdf.

MacLeay, I., Ashcroft, S. and Annut, A. 2016. Digest of United Kingdom Energy Statistics 2016. Department for Business, energy and Industrial Strategy (BEIS). London, UK. Retrieved from: https://www.gov.uk/government/uploads/system/uploads/attachment data/file/577712/DUKES 2016 FINAL.pdf.

Maritime Connector. 2017. Bulk carrier [Online] Rijrka, HR: Maritime Connector. Retrieved from: http://maritime-connector.com/bulk-carrier/.

McGrath, K. and Marinelli, M. 2012. Female workforce participation in the Australian oil and gas industry- a global comparison (Conference). 2012 APPEA National Oil and Gas Conference. 2012 Perth, AU.

MDE and DNR. 2015. Assessment of risks from unconventional gas well development in the Marcellus Shale of Western Maryland- Appendix F Noise and visual risks. Maryland Department of the Environment (MDE) and Maryland Department of Natural Resources (DNR). Baltimore, MD, USA. Rrom: http://www.mde.state.md.us/programs/Land/mining/marcellus/Pages/Risk Assessment.aspx.

$\mathrm{MDH}$. 2015. Volatile organic compounds in your home [Online] St. Paul, MN, USA: Minnesota Department of Health (MDH). Retrieved from: http://www.health.state.mn.us/divs/eh/indoorair/voc/.

Mercado, T., Alvarez, A. and Herranz, J. M. 2014. The fracking debate in the media: The role of citizen platforms as sources of information. Journal for Communication Studies, 7, 45-52. 
Ministry of Public Health (State of Qatar). 2017. Occupational health [Online] Doha, QA: Ministry of Public Health (State of Qatar). Retrieved from: https://phs.moph.gov.qa/data/occupationalhealth.

Mishra, B. C. K. and Singh, A. K. 2015. Renovation, modernization and upgradation of old hydro power station- a way forward to sustainable development, ed. Dehradun, IN: Published.

Mott MacDonald. 2010. UK electricity generation costs update. Department of Energy and Climate Change (DECC). Brighton, UK. Retrieved from: https://www.gov.uk/government/uploads/system/uploads/attachment data/file/65716/71-ukelectricity-generation-costs-update-.pdf.

Muehlenbachs, L., Spiller, E., Steck, A. and Timmins, C. 2015. The impact of the fracking boom on rents in Pennsylvania. Duke University. Durham, NC, USA. Retrieved from: http://public.econ.duke.edu/ timmins/fracking rents.pdf.

Muehlenbachs, L. A., Spiller, E. B. and Timmins, C. 2013. Shale gas development and the cost of groundwater contamination risk. Resources for the Future. Washington DC.

Mukherjee, D. and Rahman, M. A. 2016. To drill or not to drill? An econometric analysis of US public opinion. Energy Policy, 91, 341 - 351.

National Grid. 2017. Report for the year ended 31 March 2017. National Grid. London, UK. Retrieved from: http://investors.nationalgrid.com/ /media/Files/N/National-Grid-IR/resultscentre/full-year-results-statement-2016-17.pdf.

National Parks. 2013. Maps [Online] Cardiff, UK: National Parks UK. Retrieved from: http://www.nationalparks.gov.uk/visiting/maps.

Natural England. 2013. Improvement programme for England's Natura 2000 Sites: Natura 2000 map (IPENSINFO2) [Online] Worcester, UK: Natural England. Retrieved from: http://publications.naturalengland.org.uk/publication/5412847253192704.

NIDCD. 2010. Common Sounds. (Bethesda, MD, USA). Retrieved from from: http://www.nidcd.nih.gov/health/education/teachers/pages/common sounds.aspx.

npower. 2017. RWE in the UK: CR Report. npower. Swindon, UK. Retrieved from: https://www.npower.com/home/about-npower/our-responsibility/.

O'Hara, S., Humphrey, M., Andersson-Hudson, J. and Knight, W. 2015. Public perception of shale gas extraction in the UK: Two years on from the Balcombe protests. University of Nottingham. Nottingham, UK. Retrieved from: http://bettersociety.net/images/Public\%20Perceptions\%20of\%20shale\%20gas\%20in\%20the\% 20UK\%20sept131015MH.WK.JA-H.pdf.

Oil and Gas UK. 2015. UK continental shelf offshore workforce demographics report 2015. Oil and Gas UK. London, UK. Retrieved from: http://oilandgasuk.co.uk/wpcontent/uploads/2015/08/EM014.pdf.

Olson, H. C., Tutuncu, A. N. and Ladlee, J. 2012. Pooling training for shale gas development (Conference). World Gas Conference 2012. June 2012 Kuala Lumpur. Petroleum Economist 34-35.

ONS. 2016. Overview of the UK population: February 2016. Office for National Statistics (ONS). London, UK. Retrieved from: https://www.ons.gov.uk/peoplepopulationandcommunity/populationandmigration/populationesti mates/articles/overviewoftheukpopulation/february2016.

Oram, B., Halsor, S. and Redmond, B. 2011. Pennsylvania drinking water quality- Your private well: What do the results mean?, Second, Wilkes-Barre, PA, USA: Wilkes University.

Orem, W., Tatu, C., Varonka, M., Lerch, H., Bates, A., Engle, M., Crosby, L. and Mclntosh, J. 2014. Organic substances in produced and formation water from unconventional natural gas extraction in coal and shale. International Journal of Coal Geology, 126, $20-31$.

Parker, K. M., Zeng, T., Harkness, J., Vengosh, A. and Mitch, W. A. 2014. Enhanced formation of disinfection by-products in shale gas wastewater-Impacted drinking water supplies. Environmental Science and Technology, 48, 11161-11169.

Parsons Brinckerhoff. 2013. Electricity generation cost model- 2013 update of non-renewable technoligies. Department of Energy and Climate Change (DECC). Manchester, UK. Retrieved from:

https://www.gov.uk/government/uploads/system/uploads/attachment data/file/223634/2013 U pdate of Non-Renewable Technologies FINAL.pdf. 
Qatargas. 2017. Future fleet [Online] Doha, QA: Qatargas. Retrieved from: http://www.qatargas.com/English/AboutUs/Pages/FutureFleet.aspx.

Rabinowitz, P. M., Slizovskiy, I. B., Vanessa Lamers, S. J. T., Holford, T. R., Dziura, J. D., Peduzzi, P. N., Kane, M. J., Reif, J. S., Weiss, T. R. and Stowe, M. H. 2014. Proximity to natural gas wells and reported health status: Results of a household survey in Washington County, Pennsylvania. Environmental Health Perspectives, 123, 21-26.

Rigzone. 2014. Search for job opportunities [Online] Houston, TX, USA. Retrieved from: http://www.rigzone.com/jobs/search jobs.asp.

Ross, A. 2015. I won't try to block fracking plans, says North Yorkshire MP. The York Press, 7 October 2015, Retrieved from from: http://www.yorkpress.co.uk/news/13807202.I won t try to block fracking plans says Nort h Yorkshire MP/.

Salford City Council. 2015. Budget report 2015 to 2015. Salford City Council. Salford, UK. Retrieved from: https://www.salford.gov.uk/budget-2015-2016.htm.

Schafft, K. A., Glenna, L. L., Green, B. and Borlu, Y. 2014. Local impacts of unconventional gas development within Pennsylvania's Marcellus Shale region: Gauging boomtown development through the perspectives of educational administrators. Society and Natural Resources, 27, 389-404.

Small Business Trends. 2015. Interesting statistics for the top 10 social media sites [Online] Medina, $\quad \mathrm{OH}, \quad$ USA. Retrieved from: http://webtrends.about.com/od/socialnetworkingreviews/tp/Social-Networking-Sites.htm.

Social Media Today. 2015. The world's 21 most important social media sites and apps in 2015 [Online] Washington DC. Retrieved from: http://www.socialmediatoday.com/socialnetworks/2015-04-13/worlds-21-most-important-social-media-sites-and-apps-2015.

South Hook LNG Terminal. 2017. How it works [Online] Milford Haven, UK: South Hook LNG Terminal Company Ltd. Retrieved from: https://www.southhooklng.com/liquefied-naturalgas/the-supply-chain/how-it-works/.

Spence, A., Venables, D., Pidgeon, N., Poortinga, W. and Demski, C. 2010. Public perceptions of climate change and energy futures in Britain: Summary of findings of a survey conducted from January 2010 to March 2010. University of Cardiff. Cardiff, UK. Retrieved from: http://psych.cf.ac.uk/understandingrisk/docs/final report.pdf.

Stamford, L. and Azapagic, A. 2012. Life cycle sustainability assessment of electricity options for the UK. International Journal of Energy Research, 36, 1263-1290.

Standards for Highways. 1997. Traffic flow ranges for use in the assessment of new rural roads.

Standards for Highways. 1999. Traffic capacity of urban roads.

Statista. 2017a. Gross domestic product at current market prices of the United Kingdom (UK) from 2000 to 2015 (in million GBP) [Online] New York, NY, USA. Retrieved from: https://www.statista.com/statistics/281744/gdp-of-the-united-kingdom-uk-since-2000/.

Statista. 2017b. Number of social network users in the United Kingdom from 2014 to 2018 (in millions) [Online] London, UK. Retrieved https://www.statista.com/statistics/278413/number-of-social-network-users-in-the-unitedkingdom/.

Statkraft. 2017. Rheidol power station [Online] Oslo, NO: Statkraft. Retrieved from: https://www.statkraft.com/about-statkraft/visitor-centres/rheidol-visitor-centre// [Accessed July 2017].

Steinzor, N., Subra, W. and Sumi, L. 2013. Investigating link between gas development and health impacts through a community survey project in Pennsylvania. New Solutions, 23, 55-83.

Study Hills. 2012. What is tank truck? [Online]. Retrieved from: http://www.studyhills.com/topic/1223/what-is-tank-truck.

Taylor, C. and Lewis, D. 2013. Getting shale gas working. Institute of Directors. London.

ter Mors, E., Terwel, B. W. and Daamen, D. D. L. 2012. The potential of host community compensation in facility siting. International Journal of Greenhouse Gas Control, 11, Supplement, S130 - S138.

Theodori, G. L. 2012. Public Perception of the Natural Gas Industry: Data from the Barnett Shale. Energy Sources, Part B: Economics, Planning, and Policy, 7, 275-281.

Third Energy. 2016. Assets and operations: Onshore [Online] East Knapton, UK: Third Energy. Retrieved from: https://www.third-energy.com/assets-operations. 
Tsvetkova, A. and Partridge, M. D. 2016. Economics of Modern Energy Boomtowns: Do Oil and Gas Shocks Differ from Shocks in the Rest of the Economy? Energy Economics, 59, 81-95.

UKOOG, 2013, United Kingdom Onshore Oil and Gas launches shale community engagement charter [Press release] London, UK: United Kingdom Onshore Oil and Gas (UKOOG). Retrieved from: http://www.ukoog.org.uk/about-ukoog/press-releases/58-united-kingdomonshore-oil-and-gas-launches-shale-community-engagement-charter.

UK water projects online. 2015. Water company [Online] Lancaster, UK. Retrieved from: http://www.waterprojectsonline.com/water company.htm.

United States Department of Labor. 2015. Safety and health topics: Hydrogen sulfide [Online] Washington DC: United States Department of Labor. Retrieved from: https://www.osha.gov/SLTC/hydrogensulfide/hazards.html.

Upham, P., Lis, A., Riesch, H. and Stankiewicz, P. 2015. Addressing social representations in socio-technical transitions with the case of shale gas. Environmental Innovation and Societal Transitions, 16, 120-141.

Vondra, C. F. 2014. Hydraulic fracturing and North American shale plays- some concerns (Conference). 87th Annual soil management and land valuation May 212014 Ames, IA, USA. lowa State University.

Western Organization of Resource Councils. 2013. Law and Order in the oil and gas field: A review of the inspection and enforcement programs on five Western States 2013 update. Western Organization of Resource Councils. Billings, MO, USA. Retrieved from: http://worc.org/userfiles/file/Oil\%20Gas\%20Coalbed\%20Methane/Law\&Order2013.pdf.

Wetherell, D. and Evensen, D. 2016. The insurance industry and unconventional gas development: Gaps and recommendations. Energy Policy, 94, 331-335.

Williams, J., Field, L. and Lee, E. 2011. The impact of unconventional gas in Europe: $A$ report to Ofgem. Poyry (for Ofgem). Warrington. Retrieved from: https://www.ofgem.gov.uk/ofgempublications/38113/033publicreportunconventionalgasofgemlogov41.pdf.

Wire and staff reports. 2008. Poll shows public support for LNG pipeline. Mail Tribune [Online]. Retrieved from: http://www.mailtribune.com/article/20081203/NEWS/812030326\#ReaderReaction.

Zirogiannis, N., Alcorn, J., Rupp, J., Carley, S. and Graham, J. D. 2016. State regulation of unconventional gas development in the U.S.: An empirical evaluation. Energy Research and Social Science, 11, 142 - 154. 


\title{
Supporting information
}

\section{Life cycle social sustainability assessment of shale gas in the UK}

\author{
Jasmin Cooper, Laurence Stamford, Adisa Azapagic
}

S1 Nuisance: traffic

The parameters in Table S1 and Table S2 refer to the parameters in eqn. (5) in the paper.

Table S1: Data for estimation of the congestion reference flow for rural roads (Standards for Highways, 1997)

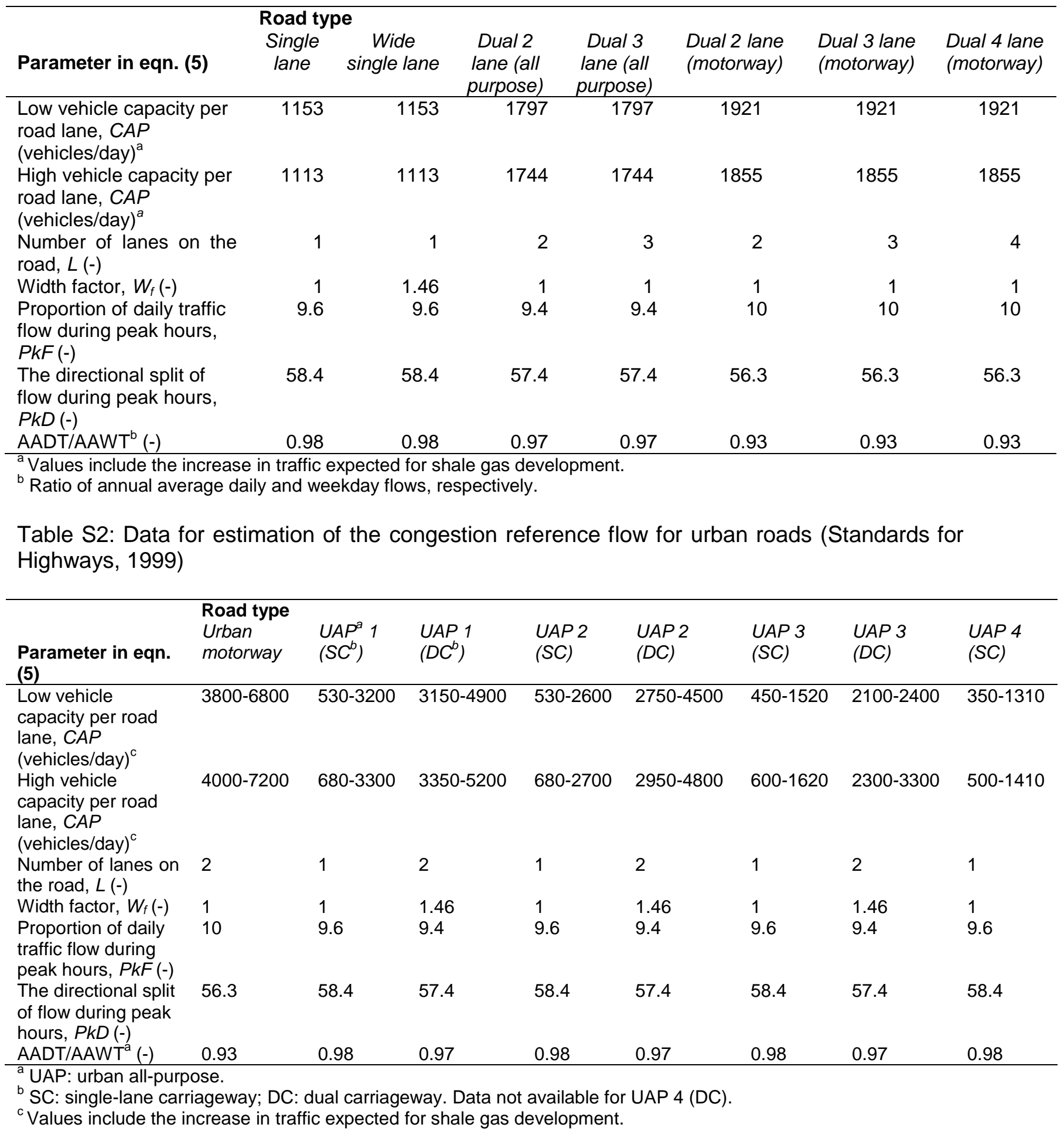




\section{S2 Media impact}

The data in Table S3 have been used in eqns. (6)-(9) in the paper to estimate the media impact index.

Table S3: Presence of different stakeholders on the social media used to calculate the media impact index ${ }^{\mathrm{a}}$

\begin{tabular}{|c|c|c|c|c|c|c|c|c|}
\hline \multirow[t]{2}{*}{ Stakeholders $(s)^{a}$} & \multicolumn{2}{|l|}{ NGOs } & \multicolumn{2}{|c|}{ Shale gas operators } & \multicolumn{4}{|c|}{ Government bodies and academia } \\
\hline & Greenpeace & $\begin{array}{l}\text { Friends of } \\
\text { the Earth }\end{array}$ & $\begin{array}{l}\text { Cuadrilla } \\
\text { Resources }\end{array}$ & iGas & Third Energy & $\begin{array}{c}\text { Department of } \\
\text { Energy and } \\
\text { Climate Change }^{b}\end{array}$ & $\begin{array}{c}\text { Environment } \\
\text { Agency }\end{array}$ & $\begin{array}{l}\text { University of } \\
\text { Manchester }\end{array}$ \\
\hline Social media metrics $(j)^{a}$ & \multicolumn{8}{|c|}{ Value of the social media metrics $\left(n_{s, j}\right)^{a}$} \\
\hline Twitter followers & $1,470,000$ & 143,000 & 1,902 & 647 & 43 & 83,500 & 352,000 & 14,400 \\
\hline Twitter tweets & 31,100 & 20,000 & 234 & 194 & 0 & 7,015 & 18,700 & 2,352 \\
\hline Facebook 'likes' & $2,328,529$ & 103,348 & No profile & No profile & No profile & No profile & 19,729 & 98,092 \\
\hline Linkedln followers & 93,563 & 5,969 & 323 & 1,227 & No profile & 16,395 & 42,418 & No profile \\
\hline Linkedln employees & $1,001-5,000$ & $51-200$ & $11-50$ & $51-200$ & No profile & $1,001-5,000$ & $10,001+$ & No profile \\
\hline Google+ followers & 61,404 & 390 & 7 & 4 & No profile & 21 & 411 & 22,344 \\
\hline Google+ views & $7,208,278$ & 169,984 & 7,035 & 5,256 & No profile & 459,320 & 6,240 & $25,807,349$ \\
\hline $\begin{array}{l}\text { YouTube subscribers } \\
\text { YouTube videos }\end{array}$ & $\begin{array}{r}102,169 \\
500_{+}\end{array}$ & $\begin{array}{r}7,737 \\
100+\end{array}$ & $\begin{array}{l}74 \\
25\end{array}$ & $\begin{array}{l}0 \\
2\end{array}$ & $\begin{array}{l}\text { No profile } \\
\text { No profile }\end{array}$ & $\begin{array}{r}827 \\
77\end{array}$ & $\begin{array}{r}1,367 \\
100+\end{array}$ & $\begin{array}{r}65,655 \\
100+\end{array}$ \\
\hline YouTube views & $50,550,940$ & $9,505,673$ & 21,827 & 3,190 & No profile & 656,366 & 591,980 & $1,358,677$ \\
\hline
\end{tabular}

\footnotetext{
${ }^{a}$ As of 13.00 on 20 October 2015. Variables $\mathrm{s}$, j and $\mathrm{n}_{\mathrm{s}, \mathrm{j}}$ refer to the variables in eqns. (6)-(9).
}

${ }^{\mathrm{b}}$ Now the Department For Business, Energy and Industrial Strategy (BEIS). 
S3 Infrastructure and resources: diversity of fuel supply

Table S4: Supply mix of other fuels used to generate electricity in the UK (MacLeay et al., 2013) $)^{\mathrm{a}}$

\begin{tabular}{|c|c|c|c|c|}
\hline Coal & Oil & Nuclear (uranium) & $\begin{array}{l}\text { Biomass } \\
\text { (woodchips) }\end{array}$ & Electricity imports \\
\hline UK (21.88\%) & UK (17.72\%) & Kazakhstan (26.72\%) & UK (5.80\%) & France $(66.37 \%)$ \\
\hline Russia (33.06\%) & Algeria (12.81\%) & Russia (17.96\%) & EU (20.56\%) & Netherlands (33.63\%) \\
\hline USA $(20.56 \%)$ & Angola (1.07\%) & Niger $(14.72 \%)$ & Canada $(19.81 \%)$ & \\
\hline Colombia (18.11\%) & Brazil $(0.37 \%)$ & Australia (13.52\%) & Egypt $(0.02 \%)$ & \\
\hline Australia (2.34\%) & Cameroon $(0.06 \%)$ & Canada (12.58\%) & Indonesia $(0.02 \%)$ & \\
\hline EU $(1.43 \%)$ & Canada $(1.88 \%)$ & US $(3.97 \%)$ & Malaysia $(0.02 \%)$ & \\
\hline Canada $(0.81 \%)$ & Congo $(0.28 \%)$ & EU $(2.69 \%)$ & Russia $(0.39 \%)$ & \\
\hline $\begin{array}{l}\text { South Africa } \\
(0.25 \%)\end{array}$ & Denmark $(3.47 \%)$ & Uzbekistan (2.47\%) & Ukraine $(0.02 \%)$ & \\
\hline \multirow{17}{*}{ Other $(1.55 \%)$} & Egypt $(0.91 \%))$ & Namibia (2.20\%) & USA (53.36\%) & \\
\hline & Equitorial Guinea (2.44\%) & Other $(2.03 \%)$ & & \\
\hline & France $(0.05 \%)$ & Malawi $(0.85 \%)$ & & \\
\hline & Hong Kong $(0.15 \%)$ & Ukraine $(0.16 \%)$ & & \\
\hline & Libya $(0.84 \%)$ & South Africa (0.14\%) & & \\
\hline & Netherlands $(0.08 \%)$ & & & \\
\hline & Nigeria $(9.90 \%)$ & & & \\
\hline & Norway (37.94\%) & & & \\
\hline & Other Africa (2.52\%) & & & \\
\hline & Other Europe $(0.13 \%)$ & & & \\
\hline & Papua New Guinea & & & \\
\hline & $(0.40 \%)$ & & & \\
\hline & Russia $(2.46 \%)$ & & & \\
\hline & Saudi Arabia (2.99\%) & & & \\
\hline & Tunisia $(0.33 \%)$ & & & \\
\hline & Venezuela $(0.87 \%)$ & & & \\
\hline & Other $(0.33 \%)$ & & & \\
\hline
\end{tabular}

\footnotetext{
${ }^{a}$ The supply mix in 2030 assumed to be equal as at present (as shown in the table) due to a lack of data for a
} future supply.

\section{References}

MacLeay, I., Ashcroft, S. and Annut, A. 2016. Digest of United Kingdom Energy Statistics 2016. Department for Business, energy and Industrial Strategy (BEIS). London, UK. Retrieved from: https://www.gov.uk/government/uploads/system/uploads/attachment data/file/577712/DU KES 2016 FINAL.pdf.

Standards for Highways. 1997. Traffic flow ranges for use in the assessment of new rural roads. Standards for Highways. London, UK.

Standards for Highways. 1999. Traffic capacity of urban roads. Standards for Highways. London, UK. 